\title{
The origin and significance of pedogenic dolomite from the Upper Permian of the South Urals of Russia
}

\author{
TIMOTHY KEARSEY* ${ }^{*}$, RICHARD J. TWITCHETT* \& ANDREW J. NEWELL $\ddagger$ \\ *School of Geography, Earth and Environmental Sciences, University of Plymouth, Drake Circus, \\ Plymouth PL4 8AA, UK \\ $\ddagger$ British Geological Survey, Maclean Building, Wallingford OX10 8BB, UK
}

(Received 2 November 2010; accepted 14 March 2011; first published online 13 September 2011)

\begin{abstract}
Pedogenic carbonate nodules from six sections spanning the continental Permian-Triassic boundary in the South Urals, Russia, were analysed. Morphological, petrographic, SEM and XRD analyses have demonstrated that many of the latest Permian palaeosols are dolomitic. This dolomite forms the microcrystalline $(5-16 \mu \mathrm{m})$ groundmass of the nodules. Later diagenetic phases, represented by coarser crystalline textures, were identified as calcite. Isotopic analysis of the microcrystalline dolomite has revealed it to be similar in isotopic composition to authigenic dolomite forming today in saline soils in Alberta, Canada. These data indicate that the dolomite found in these nodules is pedogenic, and formed in equilibrium with the atmosphere. Upper Permian pedogenic dolocretes in the studied sections are most frequent in (a) palaeosols that formed on palaeo-highs and (b) in the latest Permian period (Changhsingian), which may indicate that there was an increase in seasonality and evaporation in the South Urals region at this time. The presence of only calcitic palaeosols in the earliest Triassic may reflect a subsequent dramatic change in the basin conditions, possibly relating to the Permian-Triassic mass extinction, which stopped the conditions that are necessary for dolomite formation.
\end{abstract}

Keywords: dolomite, palaeosol, Permian, Triassic, Russia.

\section{Introduction}

The possibility that dolomite can precipitate in active surface sedimentary systems, such as soils, has long been in dispute. Dolomite is commonly associated with diagenesis in sedimentary rocks (Leeder, 1999), and some laboratory experiments have shown that it is impossible to directly precipitate dolomite from solution at atmospheric temperatures and pressures (Sherman \& Barak, 2000). Others have shown that precipitation of dolomite from solution at atmospheric temperatures and pressures can occur in the presence of certain bacteria (Roberts et al. 2004; Wright \& Wacey, 2005; Sánchez-Román et al. 2008). In addition, it has been postulated that under highly evaporative conditions, magnesium will inhibit calcite nucleation, and allow dolomite to form (Watts, 1980).

Dolomite has been observed in some modern soils in arid desert settings (Bui, Loeppert \& Wilding, 1990; Retallack \& Mindzenty, 1994; Kohut, Muehlenbacks \& Dudas, 1995; Capo et al. 2000) and in a few fossil soils (e.g. Kessler, Soreghan \& Wacker, 2001; Capo et al. 2000; Bustillo \&Alonso-Zarza, 2007). In fossil soils (palaeosols), the dolomite is thought to be related to high chemical activity of aqueous fluids, and rapid evapotranspiration of soil water (Sheldon \& Tabor, 2009). Dolomitic palaeosols are thus considered to be rare in the geological record (Sheldon \& Tabor, 2009).

†Author for correspondence: timk1@bgs.ac.uk
In this study, we report the first evidence of dolomite in palaeosols of latest Permian age, just prior to the Permian-Triassic (P-Tr) boundary. The Late Permian period was an important time in Earth history, marked by extreme climate change and biotic crisis (e.g. Kidder \& Worsley, 2005; Erwin, 2008), with evidence of increased seasonality, at least in the southern hemisphere (Tabor et al. 2007; Gastaldo \& Rolerson, 2008; Pace, Gastaldo \& Neveling, 2009; Kearsey et al. 2009). Palaeosol nodules with an unusual mineralogy have been recorded at, or very close to, the latest Permian mass extinction horizon in Antarctica, reflecting the specific atmospheric and climatic conditions associated with the biotic crisis (Sheldon \& Retallack, 2002). Palaeosol morphology and composition vary across the Permian-Triassic boundary, which may be a response to changes in climate and atmosphere (Retallack \& Krull, 1999; Krull \& Retallack, 2000; Macleod et al. 2000; Ward et al. 2005; Arche \& López-Gómez, 2005; Tabor et al. 2007; de la Horra et al. 2008; Gastaldo \& Rolerson, 2008).

Herein, the mineralogy, textures and geochemistry of well-preserved and well-dated palaeosol nodules from the Upper Permian (Changhsingian Stage) and Lower Triassic (Induan and Olenekian stages) of the South Urals, Russia, are described for the first time in order to determine the distribution, origin and significance of the palaeosol-hosted dolomite. The origin and distribution of this dolomite sheds new light on environmental change through this important interval in Earth history. 


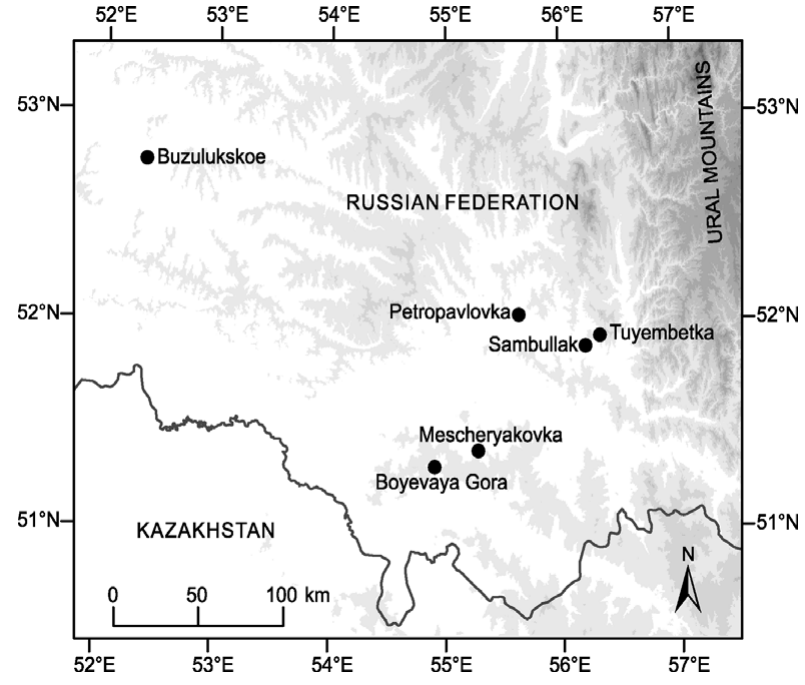

Figure 1. Map of the Orenburg region, South Urals, Russia, close to the border with Kazakhstan. The sections at Buzulukskoe, Boyevaya Gora, Mescheryakovka, Petropavlovka, Sambullak and Tuyembetka are marked.

\section{Geological setting}

$\mathrm{P}-\mathrm{Tr}$ palaeosols were examined at six locations in the Orenburg region of the South Urals, Russia (Fig. 1). Here, Upper Permian and Lower Triassic strata form the continental fill of the southern Uralian Foredeep and extend onto adjacent parts of the Russian Platform and North Caspian Basin (Newell, Tverdokhlebov \& Benton, 1999; Tverdokhlebov et al. 2002). The Late Permian depositional setting was dominated by muddy fluvial overbank deposits with minor channel sandstones, while the Early Triassic period is marked by an abrupt influx of coarse fluvial conglomerates and sandstones. This abrupt change in sedimentary facies across the $\mathrm{P}-\mathrm{Tr}$ boundary is thought to be related to reductions in vegetation cover in the drainage basin caused by the mass extinction event (Newell, Tverdokhlebov \& Benton, 1999). Distal from the Ural Mountain Belt, which formed the primary source of sediment, fluvial deposits are interbedded with aeolian sandstones (for extended palaeogeographic discussion see Newell, Tverdokhlebov \& Benton, 1999; Tverdokhlebov et al. 2002, 2005). During Late Permian and Early Triassic time, the studied sections were at an estimated palaeolatitude of $30-35^{\circ} \mathrm{N}$ (Van der Voo \& Torsvik, 2004; Taylor et al. 2009).

The continental succession is dated primarily using biostratigraphy (ostracods and vertebrates) and magnetostratigraphy (Tverdokhlebov et al. 2005; Taylor et al. 2009; Fig. 2). Three sections, Sambullak $\left(51.87993^{\circ} \mathrm{N}, 56.21167^{\circ} \mathrm{E}\right)$, Tuyembetka $\left(51.92196^{\circ} \mathrm{N}, 56.32694^{\circ} \mathrm{E}\right)$ and Boyevaya Gora $\left(51.29805^{\circ} \mathrm{N}, 54.90949^{\circ} \mathrm{E}\right)$, contain palaeosols of latest Permian age (Fig. 2). Boyevaya Gora is the only section that contains palaeosols of both earliest Triassic (Induan) and latest Permian (Changhsingian) age. Based on biostratigraphical evidence, sections from Petropavlovka $\left(52.03289^{\circ} \mathrm{N}, 55.63512^{\circ} \mathrm{E}\right)$, Mescheryakovka $\left(51.37925^{\circ} \mathrm{N}, \quad 55.28140^{\circ} \mathrm{E}\right)$ and
Buzulukskoe $\left(52.79650^{\circ} \mathrm{N}, 52.32582^{\circ} \mathrm{E}\right)$ contain palaeosols of Early Triassic age (Fig. 2; Tverdokhlebov et al. 2002).

\section{Palaeosols: general characteristics and classification}

In total 156 palaeosols were identified in the six locations, which provided a total of $580 \mathrm{~m}$ of logged section (Table 1). Palaeosol profiles range from 0.15 to $1.64 \mathrm{~m}$ thick and were identified primarily on the basis of the presence of rooting, colour mottling, angular blocky ped structure, the lack of stratification and presence of carbonate nodules. All of the palaeosols developed from fine-grained, muddy (clay and silt) or very fine sand parent material, which contained a variable proportion of sand. There are distinct differences between Permian and Triassic palaeosols.

\section{3.a. Permian palaeosols}

The Upper Permian palaeosols can be divided into separate sub-horizons (after the method of Retallack, 2001) (Table 1). The A horizon (defined as being the surface horizon of a soil; Retallack, 2001) of these palaeosols is typically $10 \mathrm{R}$ in colour (using the Munsell colour system), and are between 0.02 and $0.64 \mathrm{~m}$ thick. They are identified as an A horizon based on the presence of root traces (cf. Retallack, 1993). These root traces take the form of reddened clay infills, which are formed by the oxidation of the original organic matter of the root (cf. Retallack, 2001), and are 2-6 mm in width and $20-50 \mathrm{~mm}$ long with an obvious tapering and branching structure. The palaeosols also all contain a developed Bk horizon, which is between $0.06 \mathrm{~m}$ and $1.04 \mathrm{~m}$ thick, and represents an accumulation of carbonate (calcrete) within the lower part of the soil profile. Applying the soil carbonate classification scheme of Machette (1985), the calcrete ranges in maturity from Stage II nodules, through Stage III and IV coalesced nodules, to Stage V indurated calcrete horizons. The Stage II nodules are hard, indurated spherical or sub-spherical nodules generally less than $5 \mathrm{~cm}$ in diameter. The nodules have sharp boundaries and are found either in discrete $2-40 \mathrm{~cm}$ horizons or dispersed over $50-104 \mathrm{~cm}$. In some cases root traces are preserved as drab root haloes (Fig. 3). The Stage III horizons are formed of nodules which increase in size up to $20 \mathrm{~cm}$ and have merged and welded laterally into a discontinuous nodular bed. The Stage IV horizons are defined by the occurrence of a laminated, solid calcrete top which is $8-16 \mathrm{~cm}$ thick. These Stage IV carbonates have been found to contain ostracod fossils (Fig. 4). They are also related to channel fills which have become calcified palaeosols after the deposition of the channel fill. The Bk horizon of the Stage $\mathrm{V}$ calcrete units predominantly consists of massive micritic carbonate, which is cut by many iron-stained root traces. The top $5 \mathrm{~cm}$ of the carbonate layer show minor brecciation with pisoliths of carbonate (Fig. 3, Palaeosol Type B). 


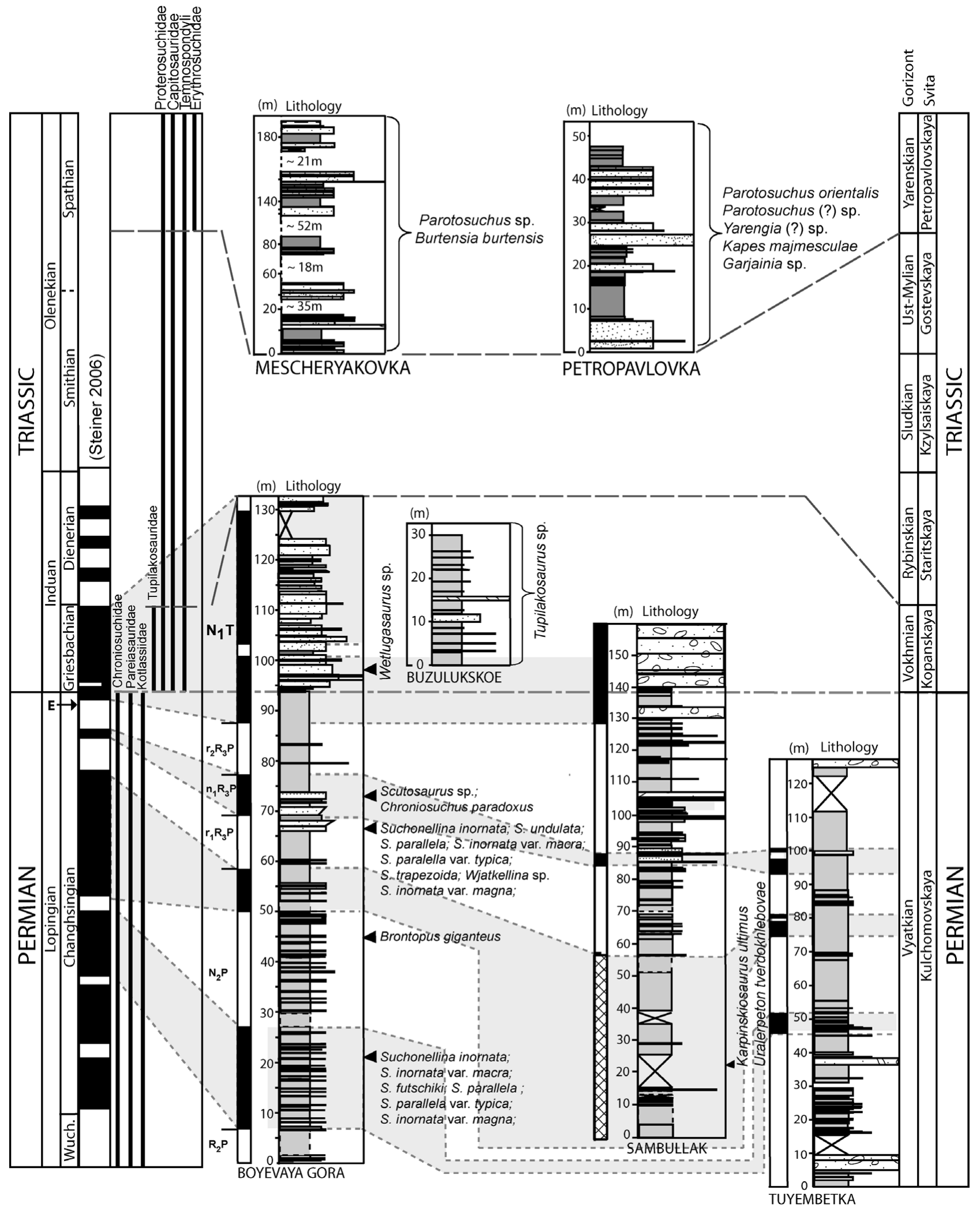

Figure 2. Biostratigraphic and magnetostratigraphic correlations of the sections in this study. Biostratigraphic control for the sections was compiled from Surkov et al. (2007) and Tverdokhlebov et al. $(2002,2005)$ with correlation to the global timescale based on Benton, Tverdokhlebov \& Surkov (2004). Palaeomagnetic data and correlations are based on Taylor et al. (2009) (including the names of the palaeomagnetic zones) and correlated to Steiner's (2006) global stratigraphy. The stratigraphy in the left column is the international stratigraphy; right column is the local Russian stratigraphy. Arrowed E indicates position of mass extinction horizon, from the global composite magnetostratigraphic correlation of Hounslow et al. (2008). 
Table 1. Features of the different pedotypes identified in the South Urals of Russia and their frequency of occurrence in the sections studied

\begin{tabular}{|c|c|c|c|}
\hline $\begin{array}{l}\text { Pedotype and } \\
\text { stratigraphic } \\
\text { occurrence }\end{array}$ & $\begin{array}{l}\text { Palaeosol horizon } \\
\text { and thickness }(\mathrm{m})\end{array}$ & Macromorphology & Frequency of occurrence \\
\hline \multirow[t]{2}{*}{ A: Permian Aridisol } & $\mathrm{A}(0.02-0.64)$ & $\begin{array}{l}\text { Moderate reddish orange }(10 \mathrm{R} 6 / 6) \text { to pale brown } \\
\text { (5YR } 8 / 1) \text {, contains branching root traces and } \\
\text { occasional } 1 \mathrm{~cm} \text { mottles and minor drab root halos. Non } \\
\text { calcareous. }\end{array}$ & $\begin{array}{l}\text { Sambullak (26) Boyevaya Gora } \\
\text { (29) Tuyembetka (65) }\end{array}$ \\
\hline & $\mathrm{Bk}(0.06-1.04)$ & $\begin{array}{l}\text { Moderate reddish orange }(10 \mathrm{R} 6 / 6) \text { to greyish red (10R } \\
\text { 4/2). Occasional root traces. Abundant carbonate (both } \\
\text { calcite and dolomite) from Stage II to VI of } \\
\text { development. }\end{array}$ & \\
\hline \multirow[t]{2}{*}{ B: Permian Vertisol } & $\mathrm{A}(0.17-0.26)$ & $\begin{array}{l}\text { Pale reddish brown }(10 \mathrm{R} 5 / 4) \text { to dark reddish brown }(10 \mathrm{R} \\
3 / 4) \text {, contains branching root traces and occasional } \\
\text { minor drab root halos. Contains pedogenic } \\
\text { slickensides. Non calcareous. }\end{array}$ & $\begin{array}{l}\text { Sambullak (4) Boyevaya Gora (3) } \\
\text { Tuyembetka (1) }\end{array}$ \\
\hline & $\mathrm{Bk}(0.06-0.58)$ & $\begin{array}{l}\text { Pale reddish brown }(10 \mathrm{R} 5 / 4) \text { to moderate orange pink } \\
\text { (10R } 7 / 4) \text {. Occasional root traces. Abundant carbonate } \\
\text { (both calcite and dolomite) Stage II to V. }\end{array}$ & \\
\hline \multirow[t]{3}{*}{ C: Permian Palustrine } & $\mathrm{R}(0.06-0.18)$ & $\begin{array}{l}\text { Moderate grey (N5) to greyish pink (5R8/2). Relict } \\
\text { lacustrine micrite; contains occasional ostracod fossils; } \\
\text { contains branching root traces. Non calcareous. }\end{array}$ & $\begin{array}{l}\text { Sambullak (1) Boyevaya Gora (5) } \\
\text { Tuyembetka (1) }\end{array}$ \\
\hline & $\mathrm{Bt}(0-0.18)$ & $\begin{array}{l}\text { Pale reddish brown }(10 \mathrm{R} 5 / 4) \text {. Occasional root traces. } \\
\text { Non calcareous. }\end{array}$ & \\
\hline & $\mathrm{Bk}(0.07-0.50)$ & $\begin{array}{l}\text { Moderate reddish orange }(10 \mathrm{R} 6 / 6) \text { to greyish red (10R } \\
4 / 2) \text {. Occasional root traces. Abundant Stage II-III } \\
\text { carbonate developed (both calcite and dolomite). }\end{array}$ & \\
\hline \multirow[t]{2}{*}{ D: Triassic Aridisol } & A $(0.08-0.09)$ & $\begin{array}{l}\text { Moderate yellowish brown (10YR 5/4) to light brown } \\
\text { (5YR6/4). Contains occasional branching root traces } \\
\text { and occasional } 1 \mathrm{~cm} \text { mottles and minor drab root halos. } \\
\text { Non calcareous. }\end{array}$ & $\begin{array}{l}\text { Boyevaya Gora (5) Buzulukskoe } \\
\text { (3) Mescheryakovka (7) }\end{array}$ \\
\hline & $\mathrm{Bk}(0.22-0.71)$ & $\begin{array}{l}\text { Moderate reddish orange }(10 \mathrm{R} 6 / 6) \text { to greyish red }(10 \mathrm{R} \\
4 / 2) \text {. Occasional root traces. Abundant carbonate Stage } \\
\text { II nodules. }\end{array}$ & \\
\hline \multirow[t]{2}{*}{$\begin{array}{l}\text { E: Triassic Aridisol } \\
\text { (Groundwater) }\end{array}$} & $\mathrm{A}(0.10-0.27)$ & $\begin{array}{l}\text { Gleyed - bluish white (5B 9/1) to light greenish grey ( } 5 \mathrm{G} \\
8 / 1) \text {. Occasional root traces. Non calcareous. }\end{array}$ & Petropavlovka (2) \\
\hline & $\mathrm{Bk}(0.20-0.35)$ & $\begin{array}{l}\text { Pale reddish brown (10R5/4). Occasional root traces. 1-5 } \\
\text { cm mottles (pale blue }-5 \mathrm{~B} 6 / 2 \text { ). Abundant carbonate } \\
\text { Stage II nodules; diffuse boundaries. }\end{array}$ & \\
\hline \multirow[t]{3}{*}{ F: Triassic Alfisols } & $\mathrm{Ag}(0.08-0.19)$ & $\begin{array}{l}\text { Light bluish grey (5B 7/1) gleyed horizon. Occasional } \\
\text { root traces, possible desiccation cracks. Non } \\
\text { calcareous. }\end{array}$ & Mescheryakovka (7) \\
\hline & $\operatorname{Btg}(0.36-1.20)$ & $\begin{array}{l}\text { Greenish yellow grey }(10 \mathrm{Y} 7 / 2) \text { to light red }(5 \mathrm{R} 6 / 6) \text {. } \\
\text { Many deep penetrating }(50 \mathrm{~cm}) \text { drab root halos (light } \\
\text { bluish grey, 5B } 7 / 1) \text {. Non calcareous. }\end{array}$ & \\
\hline & $\mathrm{Bk}(0.37-0.45)$ & $\begin{array}{l}\text { Greenish yellow grey }(10 \mathrm{Y} 7 / 2) \text {. Occasional pedogenic } \\
\text { slickensides. Occasional carbonate Stage II nodules. }\end{array}$ & \\
\hline
\end{tabular}

Above this, the Stage V calcrete units form lenses of reddened clay within the carbonate layers, which are $16 \mathrm{~cm}$ long and $8 \mathrm{~cm}$ high and pinch in and out through the bed.

Supermature carbonate beds with brecciated tops (Stage VI) were observed only at Tuyembetka (Fig. 3, Palaeosol Type A, Permian Aridisol Stage VI carbonate). They average $0.43 \mathrm{~m}$ thick but range up to $1.20 \mathrm{~m}$ thick, and they also contain thin, highly deformed, often vertically-orientated, sinuous lenses and patches of the host mudstone. The lower half of each limestone bed is commonly laminated or bedded on a scale of 1$5 \mathrm{~cm}$. Bedding is generally irregular, discontinuous and wavy. In contrast, the upper half of each limestone bed is commonly a massive, well-cemented breccia composed of centimetre-scale angular clasts set in a matrix of micrite or microspar. Overall, however, these carbonate beds are uncommon, and $46 \%$ of the palaeosol profiles show only the development of isolated Stage II nodules (ranging in diameter from $20-50 \mathrm{~mm}$ ).
The Upper Permian palaeosols can be divided into three distinct pedotypes: A, B and C (Fig. 3; Table 1). Palaeosol Type $\mathrm{A}$ is distinct by only containing A and $\mathrm{B}$ horizons, having branching root traces and abundant carbonate development (Fig. 3, Palaeosol Type A, Table 1). The uncompressed depth between the $\mathrm{Bk}$ horizon and the palaeosurface is less than $1 \mathrm{~m}$, indicating that these palaeosols may be classified as Aridisols (after Soil Survey Staff, 1999). Palaeosol Type B also contains both an A and B horizon. The A horizon contains branching root traces while the $\mathrm{Bk}$ horizon contains abundant carbonate development and is distinct by containing pedogenic slickensides (Fig. 3, Palaeosol Type B, Table 1). The presence of pedogenic slickensides in some of the palaeosols indicates that Vertisols were also present (after Soil Survey Staff, 1999). Seven palaeosols in the Permian were identified as Palaeosol Type C. These have a capping limestone horizon of between $0.06 \mathrm{~m}$ and $0.18 \mathrm{~m}$ thick, which is composed of micritic mud with $1 \mathrm{~mm}$ wide curvilinear laminations. This horizon also contains ostracod 
Palaeosol Type A - Permian Aridisol (Stage II Carbonate) KOR6
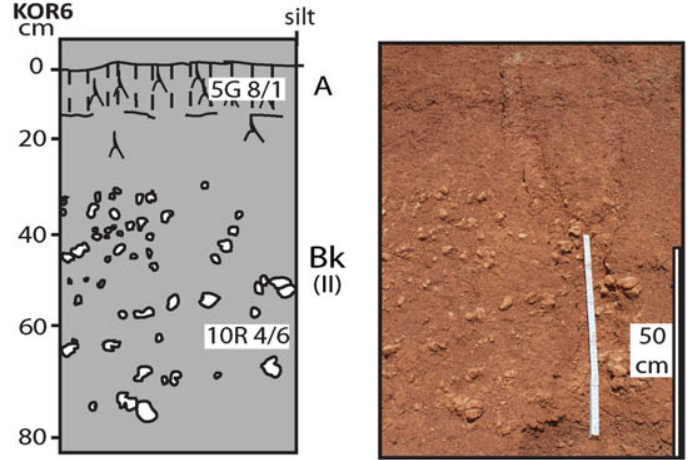

Palaeosol Type A - Permian Aridisol (Stage VI Carbonate) TuYs

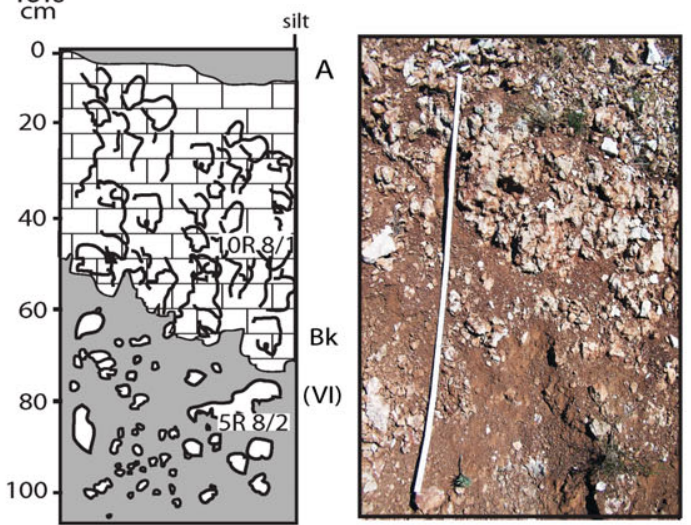

Palaeosol Type B - Permian Vertisol
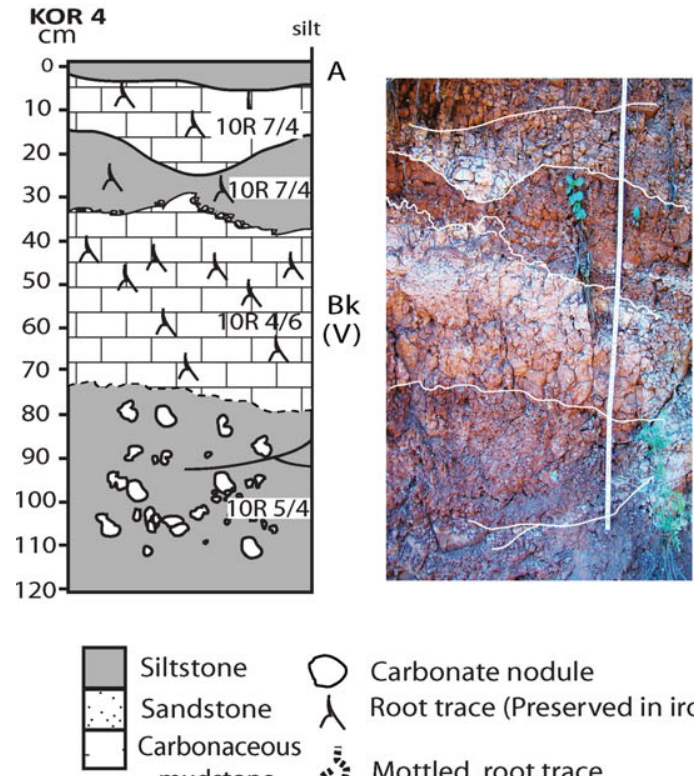

Siltstone

Sandstone $\lambda$ Root trace (Preserved in iron oxide)

Carbonaceous

mudstone Mottled root trace

\begin{tabular}{llll}
$\square$ Limestone & Mottle \\
$\equiv$ Parallel & B & 1 & \\
\hline & Bedding & 1 & Gleyed horizon
\end{tabular}

Figure 3. (Colour online) Sedimentary logs and photographs of a Palaeosol Type A (Permian Aridisol) with a Stage II carbonate horizon and Palaeosol Type A (Permian Aridisol) with a Stage VI carbonate horizon (from Tuyembetka). Also Palaeosol Type B (Permian Vertisol) and Palaeosol Type D (Triassic Aridisol), note the change in colour and thickness with respect to Type A palaeosols, and Palaeosol Type E (Triassic Aridisol Groundwater) and Palaeosol Type F (Triassic Alfisol). Note that Palaeosol Type C can be seen in Figure 4. For full descriptions of the sub-horizons within the palaeosols see Table 1.
Palaeosol Type D - Triassic Ardisol

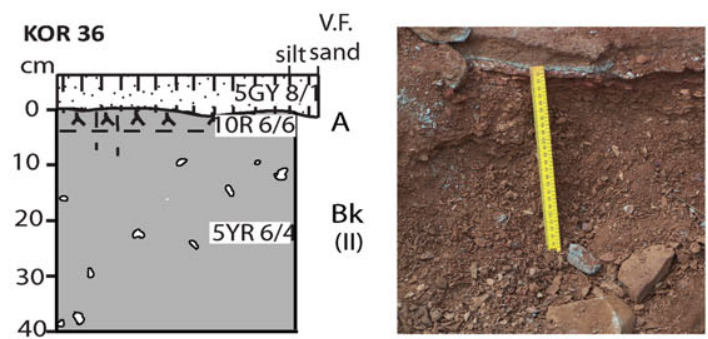

Palaeosol Type E - Triassic Ardisol (Groundwater)
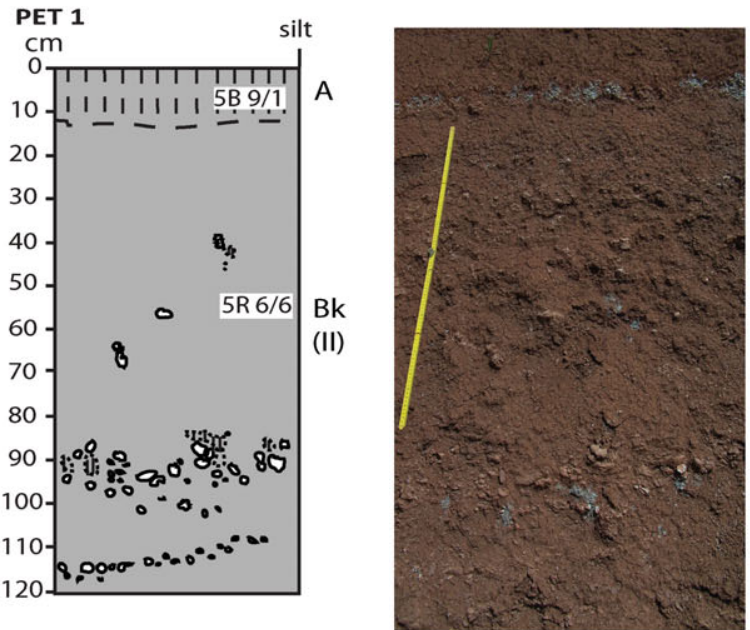

Palaeosol Type F Triassic Alfisols

MES 16

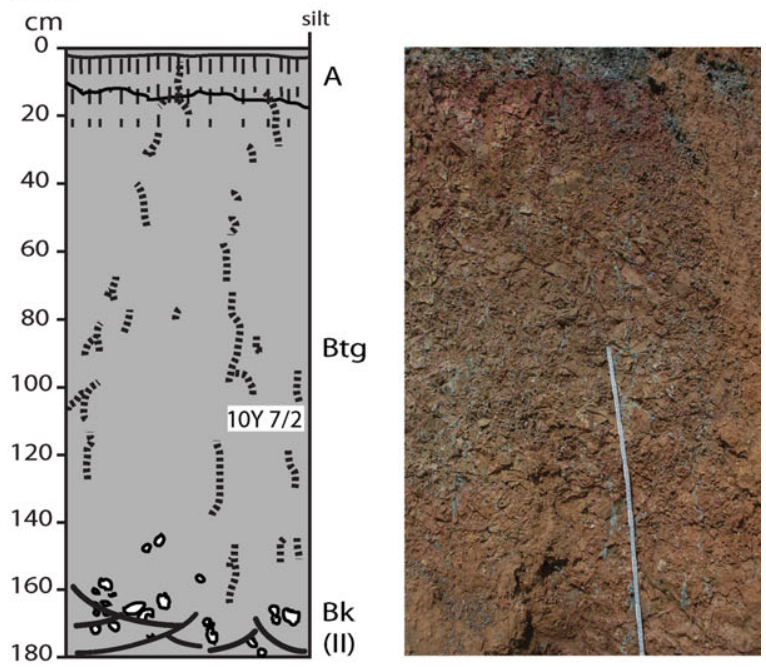



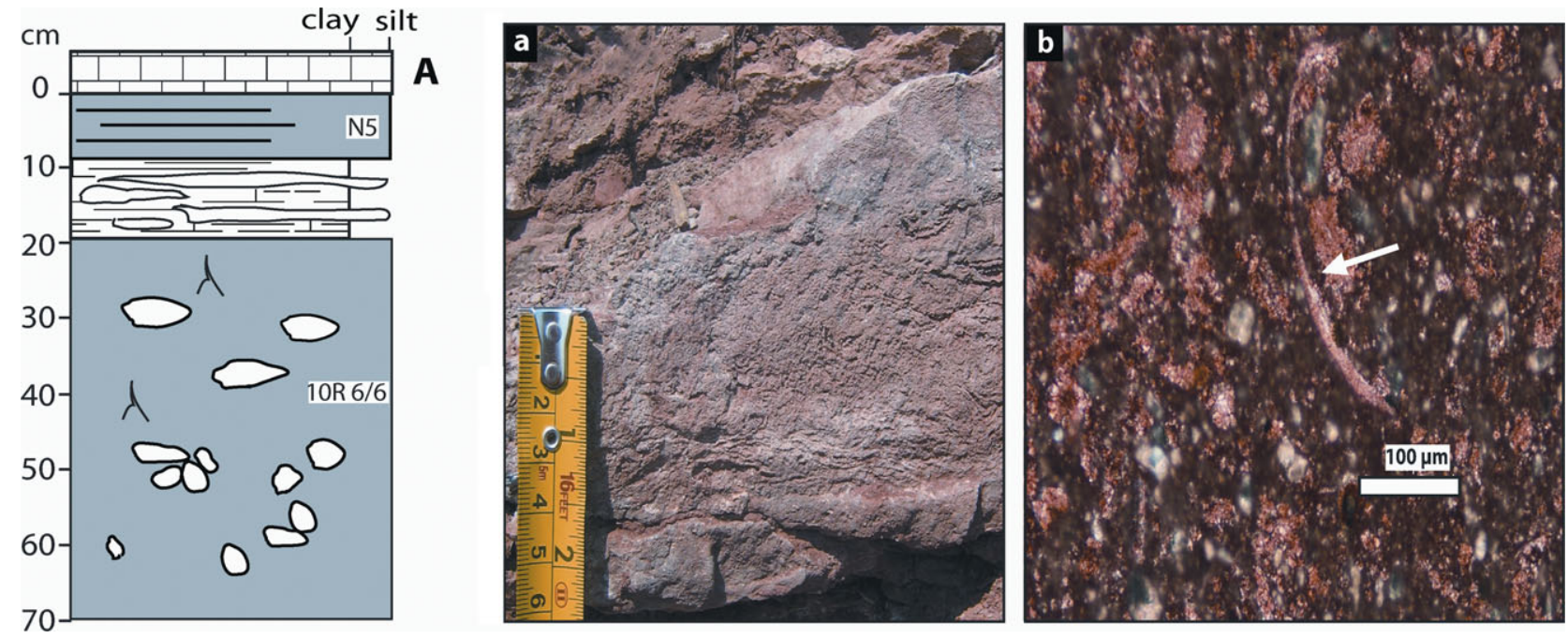

Figure 4. (Colour online) A Palaeosol Type C lacustrine-associated palaeosol showing lacustrine carbonate at the top (marked A). (a) shows the carbonate top (A) which is composed of micritic mud with $1 \mathrm{~mm}$ wide curvilinear laminations; (b) is a petrographic thin-section of (a) showing ostracod (arrowed) from lacustrine top, which has been stained with a calcite-specific stain.

fossils (Fig. 4). These were interpreted to be palustrine palaeosols (cf. Newell, Tverdokhlebov \& Benton, 1999), and probably formed from the drying out of small lakes or ponds (Palaeosol Type C, Table 1). In the context of this study, and given that it is impossible to determine the moisture regimes of ancient soils, the term 'Aridisol' purely denotes the presence of a Bk horizon less than $1 \mathrm{~m}$ from the palaeo-land surface. Using the scheme devised by Mack, James \& Monger (1993), all the palaeosols in the South Urals would be classified as Calcisols.

\section{3.b. Triassic palaeosols}

The palaeosols of the Triassic are in general a browner colour than those in the Permian (5YR to $10 \mathrm{Y}$ compared with 10R, see Fig. 3, Table 1). In common with the Permian palaeosols, they also contain root traces, but these are often associated with gleyed A and Btg horizons (Palaeosols Type E and F, Table 1). They contain carbonate nodules, but these are not developed above Stage II. The Triassic palaeosols can also be divided into three distinct pedotypes. Palaeosol Type $\mathrm{D}$ is on average thinner and thus less well developed than the Permian palaeosols (Fig. 3, Palaeosol Type D, Table 1). They contain horizons of indurated spherical or subspherical nodules generally less than $2 \mathrm{~cm}$ in diameter, which are found in discrete $22-71 \mathrm{~cm}$ horizons (Fig. 3, Palaeosol Type D). Pedotype E palaeosols are defined by having a distinct 'gleyed' A horizon, which is bluish white (5B 9/1) to light greenish grey (5G 8/1) in colour. A gleyed horizon is defined as being blue-grey in colour and strongly mottled. They are usually a result of waterlogging (Retallack, 2001). Pedotype E palaeosols also have a Bk horizon containing Stage II carbonate nodules. However, in contrast to those carbonate nodules in other pedotypes, these nodules have diffuse boundaries and can be found in distinct layers. Pedotype
$\mathrm{F}$ is defined by having both a gleyed $\mathrm{Ag}$ and Btg horizon (Fig. 3, Palaeosol Type F, Table 1). These palaeosols also have a thin, $0.37-0.45 \mathrm{~m}$ carbonate horizon (Bk), which contains spherical carbonate nodules of less than $2 \mathrm{~cm}$ in diameter that have sharp boundaries with the surrounding sediment.

Some Triassic palaeosols contain pedogenic slickensides (Fig. 3, Palaeosol Type F, Table 1), but in contrast to the Permian palaeosols these penetrate the Bk horizons. Using the criteria of Soil Survey Staff (1999), the Triassic palaeosols could be classified as Aridisols, if their Bk horizon is less than $1 \mathrm{~m}$ from the palaeosurface (Fig. 3, Palaeosol Type D, Table 1), or Alfisols, if the Bk horizon is deeper than $1 \mathrm{~m}$ (Fig. 3, Palaeosol Type F, Table 1). Using the scheme devised by Mack, James \& Monger (1993), all these palaeosols would be classified as Calcisols.

\section{Carbonate nodule mineralogy and petrography}

\section{4.a. Methods}

Powder X-ray diffraction (XRD) analyses were conducted at the University of Plymouth on a Phillips PW 1729 $\mathrm{X}$-ray generator using an X'Pert Quantify computer interface. $\mathrm{A} \mathrm{Cu}$ anode source was used with generator settings of $30 \mathrm{kV}$ and $40 \mathrm{~mA}$. Computer-based mineral identification of the traces was achieved using X'Pert High Score identification software. Manual identification was completed with reference to the Joint Committee on Powder Diffraction Standards (1971) index. Calcite was inferred by both manual and electronic identification, with a maximum XRD peak at $29.29^{\circ} 2 \theta( \pm 0.11,1 \sigma \mathrm{std})$, and a d-spacing of $3.05 \AA$. This is almost identical to the laboratory standard $(3.03 \AA)$ and to published values for calcite and calcium carbonate (3.04 $\AA$ and $3.02 \AA$, respectively) (Joint Committee on Powder Diffraction Standards, 1971). The component identified as dolomite had 
a maximum peak at $30.64^{\circ} 2 \theta( \pm 0.30,1 \sigma$ std $)$, and a d-spacing of $2.91 \AA$. This is more positive than the lab standard $(2.88 \AA)$ but is close to the published values for ferroan dolomite $(2.90 \AA)$ (Joint Committee on Powder Diffraction Standards, 1971). Some nodules recorded two peaks: one of calcite and one of dolomite (see Dataset 1 in the online Appendix at http://journals.cambridge.org/geo).

To investigate the relative crystallinity of calcite and dolomite, petrographic thin-sections were also separately stained with a calcite-specific stain, the Dickson's stain (Dickson, 1966, method after Allman \& Lawrence, 1972), and a dolomite-specific stain, alkaline alizarin red S (method after Miller, 1988). This allowed positive identification of the separate mineral phases and their locations within a carbonate nodule. A scanning electron microscope (SEM) was used to investigate the crystal shape and elemental composition of the dolomitic and calcitic carbonate nodules. The SEM images were analysed on a Jeol Jsm-6100 SEM using an Oxford Inca X-ray analysis system to identify the elemental components of different crystals. This method of element identification is energy-dispersive $\mathrm{X}$-ray spectroscopy (EDS) and was used to identify the relative levels of $\mathrm{O}, \mathrm{Mg}, \mathrm{Ca}$ and $\mathrm{Si}$.

The stable isotope $\delta^{13} \mathrm{C}$ and $\delta^{18} \mathrm{O}$ geochemistry of the nodules was investigated. The different fabrics observed in the nodules were microdrilled using a $0.75 \mathrm{~mm}$ diameter drill, taking samples of between 300-500 $\mu \mathrm{g}$. The carbonate powders were reacted with $100 \%$ phosphoric acid at $90{ }^{\circ} \mathrm{C}$. The evolved $\mathrm{CO}_{2}$ was analysed on a $\mathrm{GV}$ Instruments Isoprime mass spectrometer with a Gilson Multiflow carbonate autosampler at the University of Plymouth. The triplicate isotope values were averaged for each sample, and any results below $1.2 \mathrm{nA}$ were removed from the dataset and rerun. The results were calibrated against Vienna Peedee Belemnite (VPDB) using the international standard NBS-19 (National Bureau of Standards $19 ; \delta^{13} \mathrm{C}=1.95, \% \circ \delta^{18} \mathrm{O}=-2.20 \%$ ). Reproducibility of replicate analyses was $\delta^{13} \mathrm{C}= \pm$ $0.16 \%$ and $\delta^{18} \mathrm{O}= \pm 0.36 \%$.

\section{4.b. Results: petrography}

All carbonate horizons primarily consist of cryptocrystalline carbonate with crystal sizes from micrite to spar. Some $50-70 \%$ of an individual nodule is composed of a muddy crypto- to microcrystalline groundmass of carbonate (the microcrystalline crystals being between 5 and $16 \mu \mathrm{m}$ and often show a rhombic habit) (Fig. 5b-d). The cryptocrystalline component of the nodules often shows a characteristic 'clotted' fabric of cryptocrystalline concretions of 500-1500 $\mu \mathrm{m}$ in diameter (Fig. 5b) surrounded by a coarser microcrystalline matrix (cf. Wright \& Tucker, 1991; Quast, Hoefs \& Paul, 2006). Occasional $(<1 \%)$ 'floating' grains of very fine quartz $(95 \mu \mathrm{m})$ are observed that have been replaced by the growth of carbonate (Fig. 5c). All the carbonates show alpha calcrete microfabric calcrete micromorphology

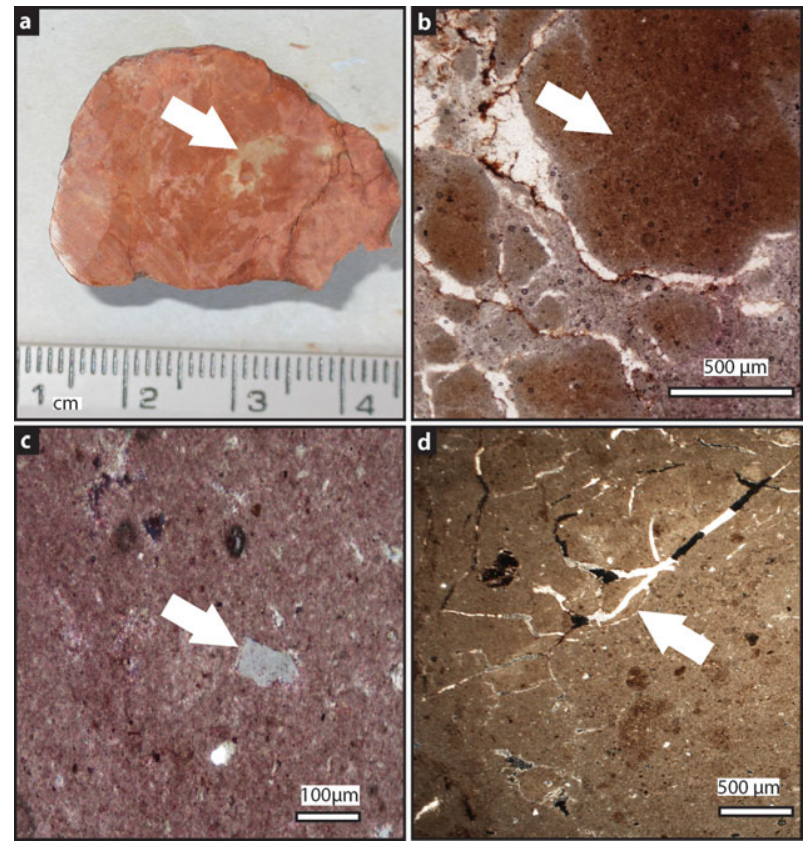

Figure 5. (Colour online) The morphological and petrological features seen in the carbonate nodules. (a) shows sharp dolomitic nodule boundaries and central core (arrowed) from a Type A palaeosol. (b) Photomicrograph of a dolomitic carbonate nodule from a Type A palaeosol with clotted fabric (arrowed). (c) Photomicrograph showing a floating quartz grain (arrowed) surrounded by crypto-microcrystalline calcite from a Type D palaeosol. (d) A photomicrograph showing a sinuous vein (arrowed) filled in with euhedral calcite. The cryptocrystalline groundmass is dolomitic from a Type B palaeosol.

(Wright \& Tucker, 1991). Many appear to have formed around a core of less consolidated soil matter (Fig. 5a), where a ped is used as a centre for nucleation (Khadkikar, Chamyal \& Ramesh, 2000). Sinuous veins of anhedral to euhedral calcite are found cutting across some nodules (Fig. 5d). The vein crystals have distinct crystal boundaries from the surrounding micro- and cryptocrystalline groundmass.

The only exceptions to these are the carbonate layers from the Type $\mathrm{C}$ palaeosols (Fig. 4). These consist of $10 \%$ very fine sand/silt grade sub-rounded quartz grains surrounded by a groundmass of micritic cryptocrystalline carbonate. Also included within this groundmass are occasional bioclasts such as ostracod fossils preserved in calcite. There are also patches of coarser crystalline calcite approximately $25 \mu \mathrm{m}$ in diameter, which appear to be roughly spherical in shape and may be fills of spherical voids in the rock or calcified pellets. These carbonate features are similar to those described as beta calcrete microfabrics (Wright \& Tucker, 1991).

XRD on 1312 carbonate samples revealed that most nodules are composed primarily of either calcite or dolomite (see Dataset 1 in the online Appendix at http://journals.cambridge.org/geo). In those nodules that contained dolomite, the microcrystalline and cryptocrystalline parts of the fabric took up the dolomite stain (Fig. 6aii). The dolomite occurs in the 

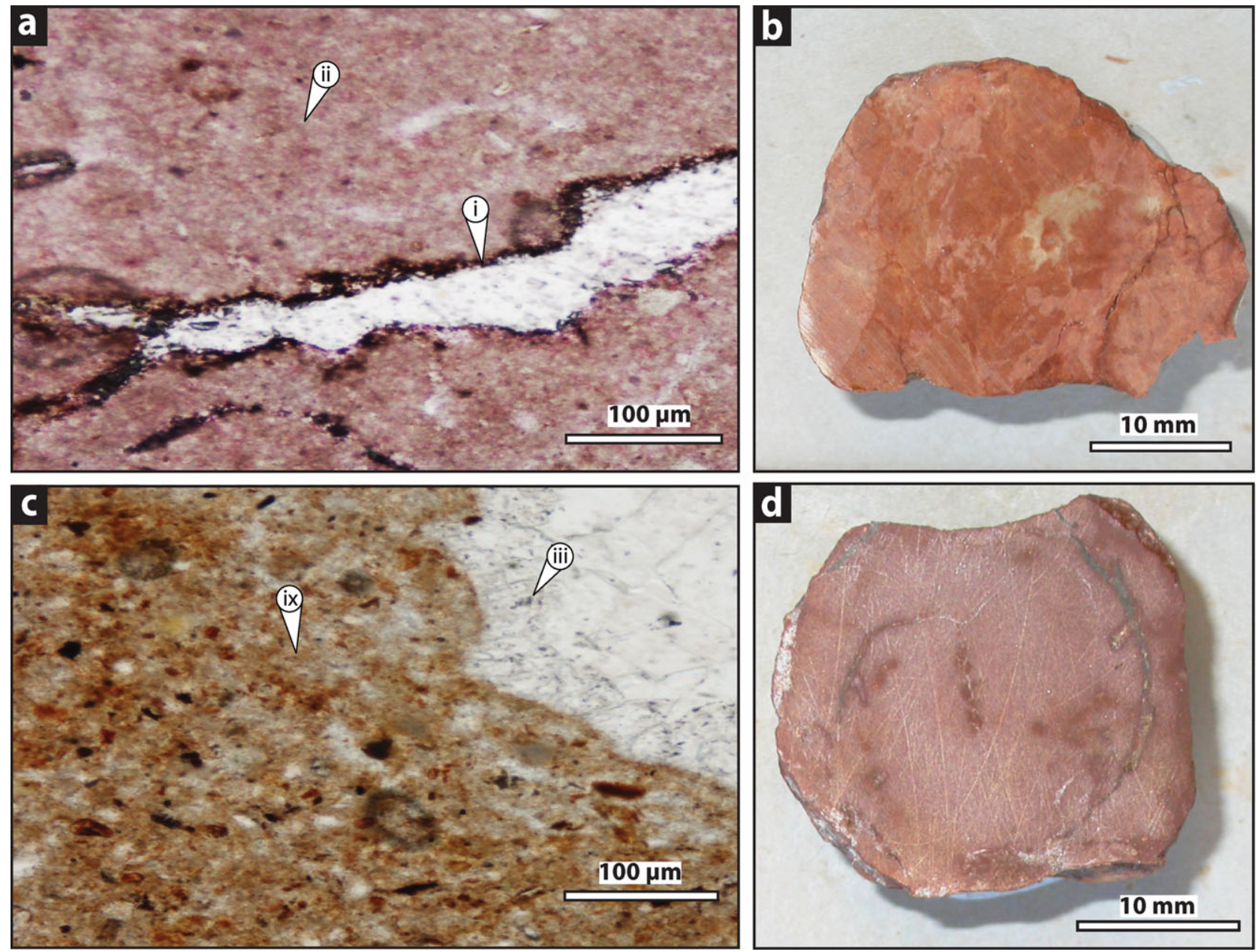

Figure 6. (Colour online) Two petrographic slides both from carbonate nodules from Type A palaeosols (a, c), both stained with dolomite-specific stain, and the respective nodules from which the slides came (b, d). (a) is a dolomitic nodule where (i) is the later calcitic sinuous vein which has not taken up the stain and (ii) is the dolomitic cryptocrystalline groundmass which has taken up the stain. (b) is the nodule from which slide (a) was taken. (c) is a calcite nodule where both the later vein filling calcite (iii) and cryptocrystalline calcite (ix) have not taken up the stain. (d) is the nodule from which slide (c) was cut.

primary, micritic part of the nodule (cf. Wright \& Tucker, 1991; Spötl \& Wright, 1992; Quast, Hoefs \& Paul, 2006), and is not related to any morphological or petrological variation within the nodules (Fig. 6). Nodules that recorded both a calcite and a dolomite peak using XRD were stained with a calcite-specific stain (Dickson's stain). This demonstrated that the calcite is present in sinuous veins of anhedral to euhedral calcite randomly cutting across most of the nodules. The elongated calcite crystals are $5-15 \mu \mathrm{m}$ in width and generally $150-50 \mu \mathrm{m}$ in length. The vein crystals have distinct boundaries from the surrounding micro- and cryptocrystalline groundmass (Fig. 6ai, ciii). These veins may also grow around patches of crypto- and microcrystalline micrite (Fig. 6a, c).

SEM revealed that the areas that make up the densest parts of the clotted texture in the dolomitic nodules are composed of dolomite rhombs of c. $2-5 \mu \mathrm{m}$ in size (Fig. 7a). Elemental analyses of these areas showed prominent peaks in $\mathrm{Ca}, \mathrm{C}, \mathrm{O}$ and $\mathrm{Mg}$. The sparry vein fill, by contrast, lacks a prominent $\mathrm{Mg}$ peak confirming that it is indeed calcite. The calcite crystals envelop the dolomite rhombs (Fig. 7b). SEM carried out on the calcitic nodules shows that the calcitic nodules have slightly larger crystals $(c .10 \mu \mathrm{m})$, which have an amorphous shape (Fig. 8). Elemental analyses of these areas showed prominent peaks in $\mathrm{Ca}, \mathrm{C}$ and $\mathrm{O}$, and other areas show peaks in $\mathrm{Si}, \mathrm{Al}$ and $\mathrm{O}$, suggesting the presence of quartz or clays (Fig. 8).

\section{4.c. Results: isotopes}

Isotope values from micritic parts of the dolomitic nodules that have a clotted texture ranged from $\delta^{13} \mathrm{C}$ $+2.60 \%$ to $-5.62 \%$ (VPDB) and $\delta^{18} \mathrm{O}+2.52 \%$ to $-8.28 \%$ (VPDB), while the calcitic nodules ranged from $\delta^{13} \mathrm{C}+0.46 \%$ to $-11.06 \%$ (VPDB) and $\delta^{18} \mathrm{O}$ $-2.52 \%$ to $-10.87 \%$ (VPDB) (Fig. 9). The dolomitic micrite $\delta^{13} \mathrm{C}$ isotope values were on average $3 \%$ more positive than the calcitic micrite, while $\delta^{18} \mathrm{O}$ values were $6 \%$ more positive. In both cases the calcite and dolomite from Type A, C and D palaeosols have more positive $\delta^{18} \mathrm{O}$ values. Although in all the sections the vast majority of organic carbon has been oxidized leaving drab root halos and reddened clay, three samples of organic carbon were recovered from 

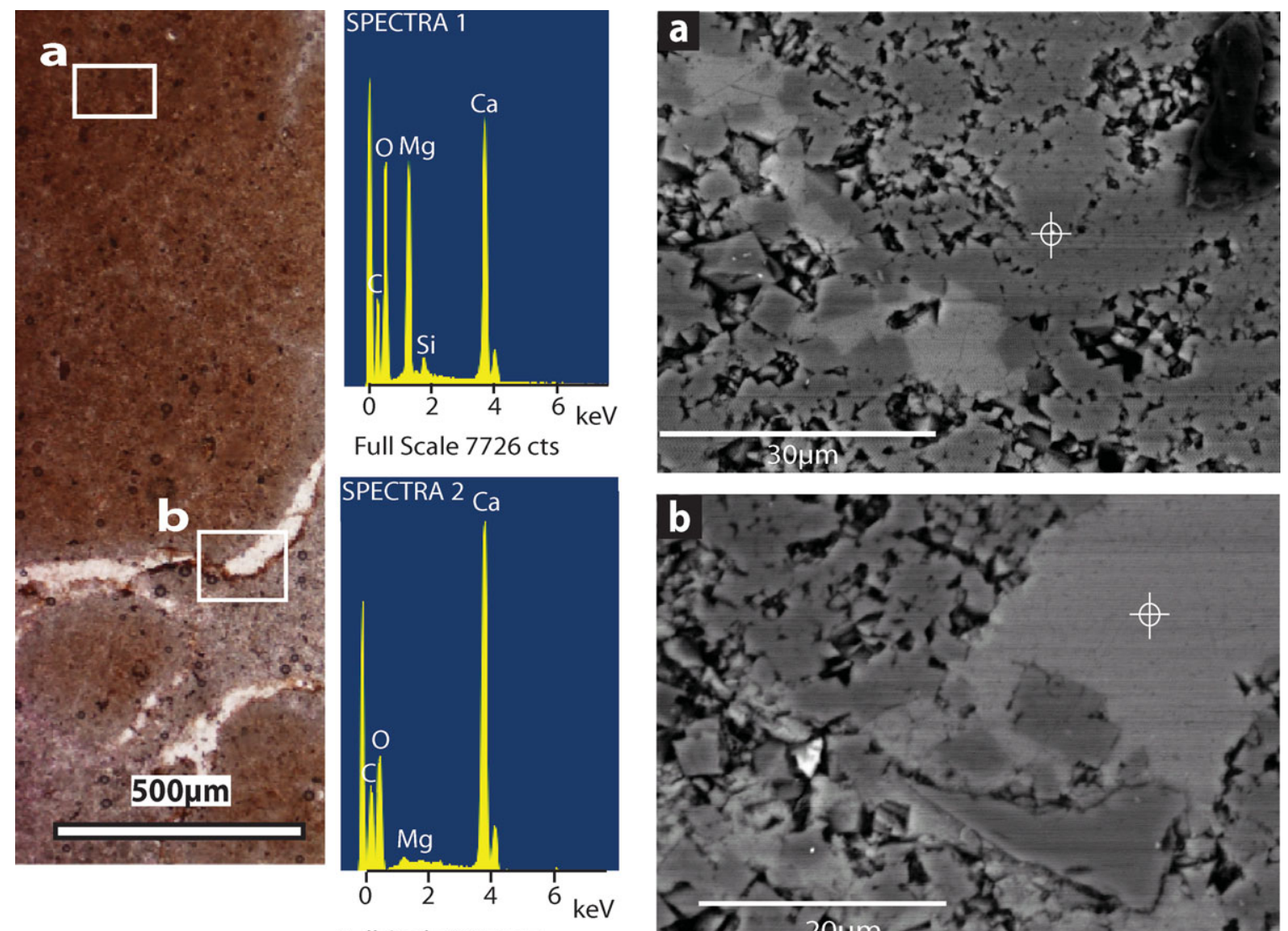

Full Scale 8612 cts

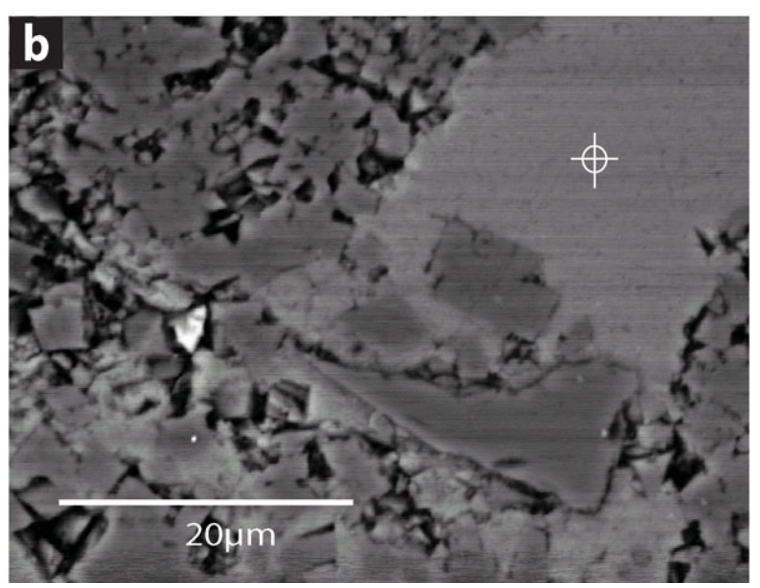

Figure 7. (Colour online) SEM results from different parts of a dolomitic nodule from a Type A palaeosol (see photomicrograph on left). Area (a): elemental analysis of a cryptocrystalline area, showing a high Mg peak (Spectra 1). Area (b): elemental analysis of sinuous vein, with no Mg peak (Spectra 2).

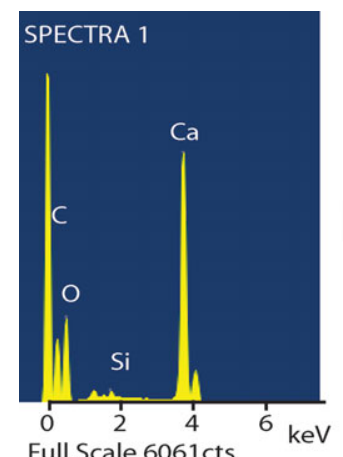

Full Scale 6061cts

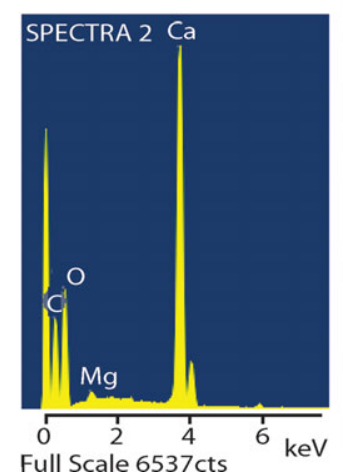

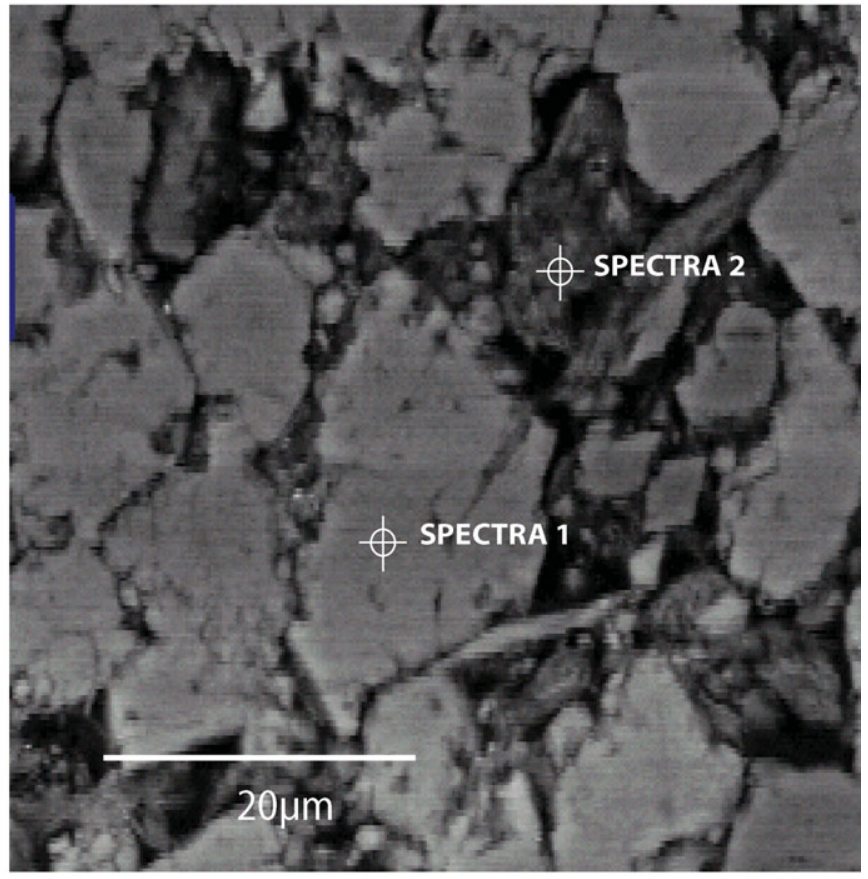

Figure 8. (Colour online) SEM results from different parts of the cryptocrystalline part of a calcitic nodule from a Type A palaeosol. The spectra are of the calcitic area (Spectra 1) and areas of clay/silt found in between (Spectra 2). 


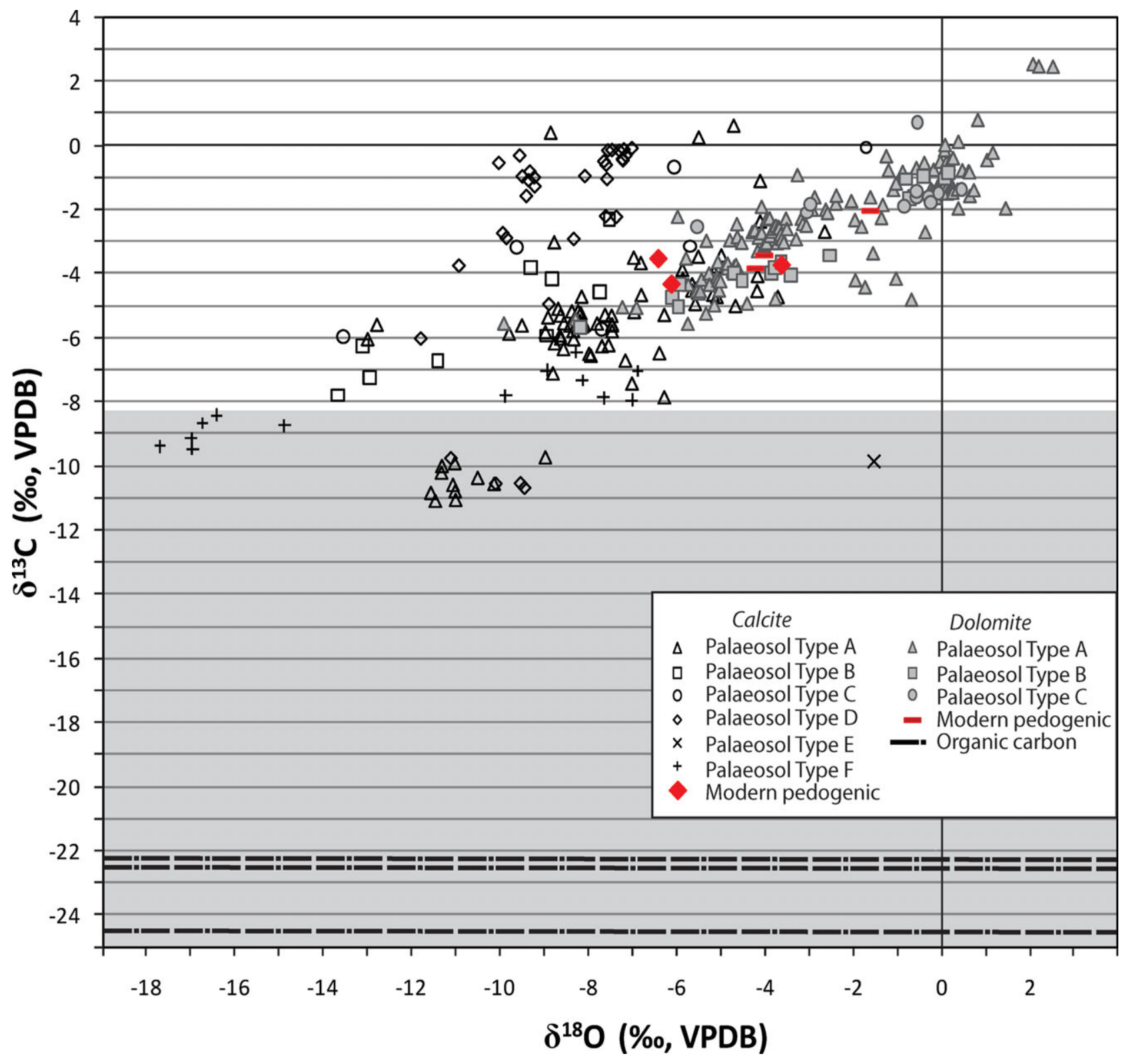

Figure 9. (Colour online) Isotopic data from the micritic fraction of the pedogenic nodules from the sections in the South Urals, Russia, and the organic carbon values recovered from Sambullak (see Dataset 2 - stable isotope results for values in the online Appendix at http://journals.cambridge.org/geo). The isotopic values for modern pedogenic calcite and dolomite are from Kohut, Muehlenbacks \& Dudas (1995) from soils from Alberta, Canada. The grey shaded area is the area of carbonate that can be explained purely by the oxidation of organic matter in the soil (see text).

Sambullak (Fig. 9) which have an average $\delta^{13} \mathrm{C}$ organic value of $-23.04 \%$.

\section{Discussion}

Previous studies on the sedimentary facies of the South Urals across the P-Tr boundary have identified that the presence of pedogenic carbonate and root development within these sections is part of a terrestrial fluvial system (Newell, Tverdokhlebov \& Benton, 1999; Surkov et al. 2007). This has been used to suggest the palaeosols formed in a semi-arid to sub-humid environment (Surkov et al. 2007). This interpretation is consistent with the more detailed investigation into the palaeosols undertaken in this study, as the majority of the palaeosols show closest affinity to modern Aridisols, which are found in semi-arid to arid environments (Retallack, 1993, 2001). Previous studies also identify the presence of shallow ephemeral lakes, which are thought to be present in the sections (Newell, Tverdokhlebov \& Benton, 1999). These have also been identified in this study and have shown a level of pedogenic alteration (Fig. 4; Table 1). These lacustrineinfluenced Type $\mathrm{C}$ palaeosols only represent 7 out of 156 palaeosols identified in this study (see Table 1).

\section{5.a. Origin of dolomite}

The origin of dolomite in palaeosols and the processes that allow its precipitation are disputed. Although it has been observed in many palaeosols (e.g. Kessler, 
Soreghan \& Wacker, 2001; Capo et al. 2000; Bustillo \& Alonso-Zarza, 2007) and some modern soil profiles (Bui, Loeppert \& Wilding, 1990; Kohut, Muehlenbacks \& Dudas, 1995; Capo et al. 2000), it is still considered to be exceedingly rare in the geological record (Sheldon \& Tabor, 2009).

This study has shown, however, that the Upper Permian palaeosols of the South Urals commonly contain dolomite. Understanding the origins of this dolomite, and the timing of its formation, may shed light on this debate, and have wider implications for our understanding of the palaeosol record.

Petrographic analysis of the nodules shows that they have a clotted texture, which is commonly associated with nodule growth in vadose environments (Wright \& Tucker, 1991; Quast, Hoefs \& Paul, 2006) (Fig. 5b). This interpretation is also supported by the presence of 'floating' grains of very fine quartz that have been replaced by the growth of carbonate (Khadkikar, Chamyal \& Ramesh, 2000; Quast, Hoefs \& Paul, 2006) (Fig. 5c). The dolomite-specific staining and SEM analyses demonstrate that, in nodules where it occurs, dolomite comprises the microcrystalline and cryptocrystalline parts of the nodules. These microcrystalline and cryptocrystalline parts of the nodules have clotted textures and alpha fabrics, features (Fig. 5) that have been interpreted by Wright \& Tucker (1991), Khadkikar, Chamyal \& Ramesh (2000), Alonso-Zarza (2003) and Quast, Hoefs \& Paul (2006) to have pedogenic origins. The only carbonate that has a different appearance to this is that from the Type $\mathrm{C}$ palaeosols, which contain ostracod fossils and fabrics that may be associated with ephemeral lakes (AlonsoZarza, 2003).

Spar crystals are present in the nodules (Figs $5 \mathrm{~d}$, 6ai, 7b) and indicate a later phase of crystallization, which filled in cavities created by shrinking and swelling, or by rootlet action (Wright \& Tucker, 1991; Khadkikar, Chamyal \& Ramesh, 2000; Quast, Hoefs \& Paul, 2006). The spar crystals have distinct boundaries separating them from the surrounding micro- and cryptocrystalline groundmass, suggesting two phases of crystallization, with the spar forming after the groundmass (Fig. 6ai, aii). This indicates that the spar is therefore secondary and formed during diagenesis and lithification. SEM (Fig. 7) and calcite-specific staining (Fig. 6) show that these spar crystals are all calcitic. All of the fabrics associated with diagenesis are characterized by the precipitation of calcite. None of the diagenetic fabrics contain dolomite, and the fabrics that are composed of dolomite are all primary. It is plausible that the dolomite could be an early mimetic replacement of calcite cryptocrystalline groundmass. This would, however, have had to have been very early in the diagenetic history of the carbonate as all the later cements are calcitic. However, in palaeosols where such early dolomitic replacement has been observed such as those described by Gómez-Gras \& Alonso-Zarza (2003), an isopachous rim of acicular dolomitic crystals which formed during the diagenetic overprint process is seen. The dolomitic carbonates from the palaeosols in this study show no such overprint (Fig. 6a).

\section{5.b. Lacustrine/groundwater origin}

Primary dolomite, formed through surface and groundwater processes rather than diagenetic or metamorphic routes, is usually associated with lacustrine conditions (Watts, 1980; Colson \& Cojan, 1996; Bustillo \& Alonso-Zarza, 2007). The Type C palaeosols which contain dolomite are certainly associated with evidence of lacustrine conditions, such as those occurring with thin, ostracod-bearing limestones (Fig. 4, Type C palaeosols, Table 1). These nodular dolocretes precipitated in the vadose zone as the lakes dried out (Colson \& Cojan, 1996; Alonso-Zarza, 2003; Quast, Hoefs \& Paul, 2006). Previous studies have inferred the presence of ephemeral lakes and ponds during Late Permian time in the study area from sedimentological evidence (Newell, Tverdokhlebov \& Benton, 1999). The evaporation of such ephemeral lakes and ponds would produce Mg-rich waters, which would precipitate dolomite rather than calcite (cf. Calvo et al. 1995). Elevated carbonate/bicarbonate concentrations in the lake waters would result in the direct precipitation of cryptocrystalline dolomite (cf. del Cura et al. 2001).

The majority of dolomite nodules from the Upper Permian of the South Urals are, however, not associated with evidence of lacustrine conditions (Fig. 10). They occur in palaeosols identified as Aridisols and Vertisols (Type A and Type B palaeosols, Table 1) containing Stage II carbonate nodules, which are morphologically identical to palaeosols containing just calcite nodules (Table 1; Fig. 10). The dolomite is also present in Stage III, V and VI developed calcretes. All Type $\mathrm{A}$ and $\mathrm{B}$ palaeosols are well rooted throughout with branching rootlets, indicating that the soil could not have been waterlogged for a prolonged period. Equally, Type A and B palaeosols show no evidence of gleyed horizons, which if present would indicate permanent water logging of these palaeosols (cf. Retallack, 2001). The evidence indicates that the dolomite present in those palaeosols could not have formed through the influence of lacustrine waters.

Geochemistry may provide an additional means of determining whether individual palaeosols formed under waterlogged conditions. Based on their interpretations of the isotopic signature of calcitic palaeosols, Tabor et al. (2007) argue that in a Karoo Basin Permian-Triassic section, palaeosols were isolated from the atmosphere during their formation, under permanently waterlogged conditions. The authors argued that $\delta^{13} \mathrm{C}$ values of pedogenic calcite that fall within $+14.8 \%$ of the $\delta^{13} \mathrm{C}$ isotopic composition of co-occurring organic matter can be entirely explained through the $\mathrm{CO}_{2}$ produced during oxidation of organic matter in a closed system (Tabor et al. 2007).

If this argument is applied to the South Urals palaeosols, using $\delta^{13} \mathrm{C}$ values of organic carbon recovered 

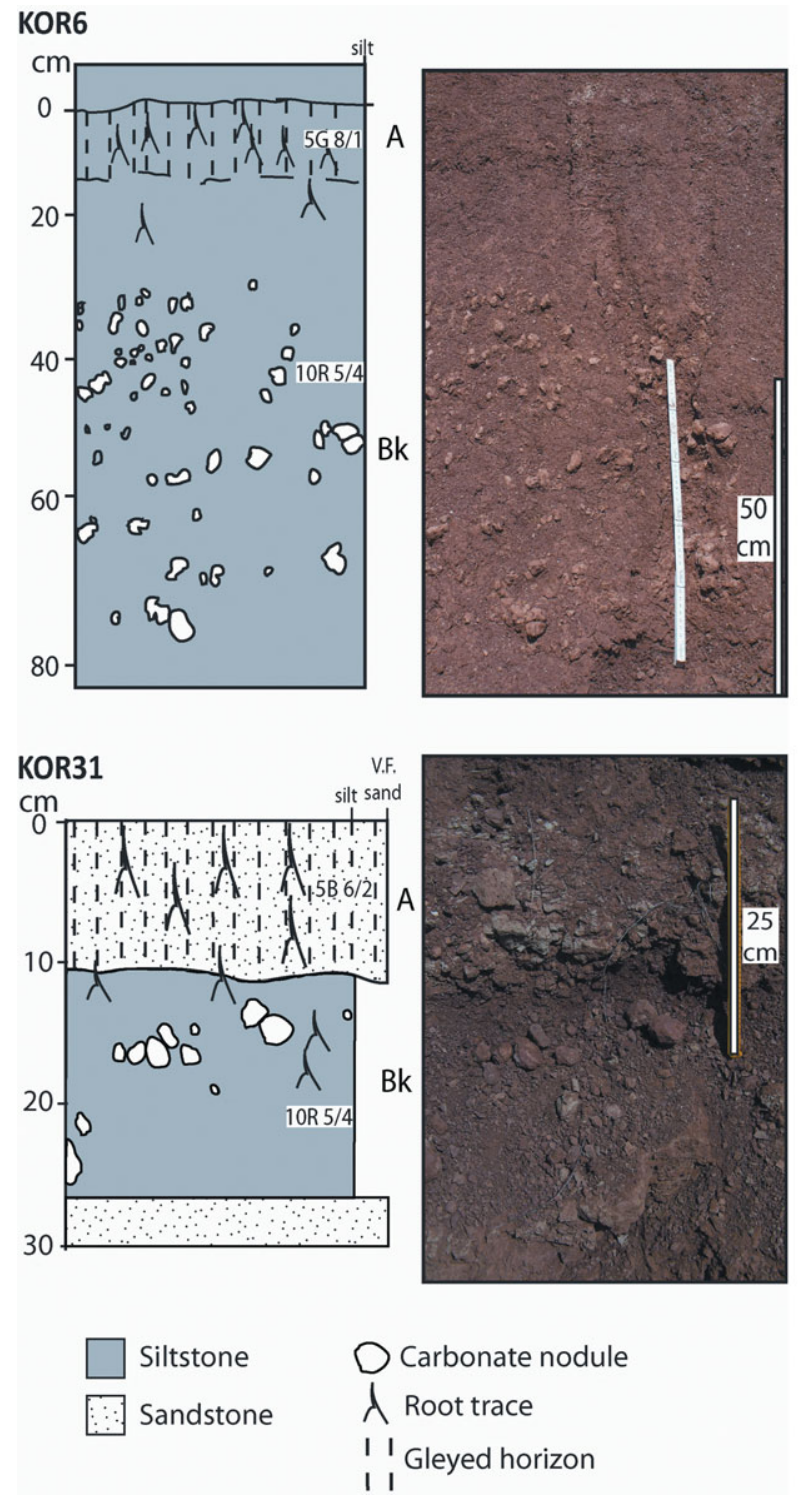

Figure 10. (Colour online) Two Type A palaeosols from Boyevaya Gora where the carbonate is of pedogenic origin. KOR6 shows a pedogenic dolomitic palaeosol that is very similar to the palaeosol seen in KOR31, which is entirely calcitic (see Dataset $1-\mathrm{XRD}$ results in the online Appendix at http://journals.cambridge.org/geo).

from Sambullak (Fig. 9), then any calcite with $\delta^{13} \mathrm{C}$ values below $-8.24 \%$ (VPDB) could have formed in a closed system, under waterlogged conditions, and thus have a groundwater origin. Although, some calcitic nodule isotope values do fall within this field (Fig. 9), they are mainly from Triassic Alfisols (Type F palaeosols) and Triassic groundwater Aridisols (Type E palaeosols) in the Mescheryakovka section, which also have obvious morphological evidence for a groundwater origin and are very different in morphology to the Sedibo palaeosols (cf. Retallack, Smith \& Ward, 2003) analysed by Tabor et al. (2007). The geochemical data therefore suggest that the majority of the studied palaeosol nodules do not have a groundwater origin, but instead formed in an open system in equilibrium with atmospheric $\mathrm{CO}_{2}$. It has also been observed that positive linear covariant trends observed between $\delta^{13} \mathrm{C}$ and $\delta^{18} \mathrm{O}$ similar to that observed in the South Urals palaeosols (Fig. 9) is indicative of carbonate formed in an open vadose system (Ufnar, Gröcke \& Beddows, 2008).

Furthermore, the relatively positive $\delta^{13} \mathrm{C}$ value for the organic matter recovered from the section at Sambullak may indicate arid conditions as in such conditions, reduced photosynthetic fractionation under water-stressed conditions leads to more positive isotopic values (Bestland \& Krull, 1999; Wynn, 2007). There are also a cluster of Permian Aridisols with $\delta^{13} \mathrm{C}$ values below $-8.24 \%$ (VPDB). These samples also have $\delta^{18} \mathrm{O}$ values below $-8.00 \%$ (Fig. 9), which has been observed in other Permian sections (Ghosh, Ghosh \& Bhattacharya, 2001; Tabor et al. 2007) and may be related to extreme atmospheric conditions associated with the mass extinction.

It has been noted that in marine and lacustrine environments mimetic dolomite can replace original fabrics and textures such as micrite at low temperatures (Vahrenkamp \& Swart, 1994; Williams \& Krause, 1998). It is therefore possible that evaporating lacustrine waters could result in the formation of microcrystalline dolomite as a replacement fabric for original calcite. In this study, however, the section at Tuyembetka has 28 palaeosols containing apparent pedogenic dolomite (Fig. 11), and this section has no evidence for lacustrine deposits or Type $\mathrm{C}$ palaeosols. Several lines of evidence suggest that Tuyembetka represents a palaeohigh. In the uppermost Permian of Tuyembetka there are many more very welldeveloped (mature) palaeosols (Fig. 3), and fewer fluvial channels than at other sections studied. In addition, palaeomagnetic studies also show that this section is highly condensed compared to other sections in the basin (Taylor et al. 2009). Equally those pedogenic dolomites that occur just beneath the $\mathrm{P}-\mathrm{Tr}$ boundary at Boyevaya Gora are not associated with any evidence of lacustrine deposits, although such deposits do occur much lower in the Permian at that section (the Type $\mathrm{C}$ palaeosols). Thus we conclude that the pedogenic dolomite horizons in the Upper Permian of the South Urals are not caused by mimetic replacement by evaporative lacustrine waters as they are texturally distinct from the lacustrine-influenced Type C palaeosols and they show an isotopic signal indicative of carbonate formed in an open vadose system.

\section{5.c. Pedogenic origin}

Multiple lines of evidence thus indicate that the dolomite present in Type A and B palaeosols in most Upper Permian sections from the South Urals was precipitated as a primary mineral phase during pedogenesis. Primary, pedogenic dolomite nodules not associated with ephemeral lakes are very rare. Pedogenic dolomite has been identified in modern soils, associated with weathered basaltic rocks producing 
elevated $\mathrm{Mg} / \mathrm{Ca}$ ratios (Capo et al. 2000). There is no petrographic evidence of tephra or other volcanic or basaltic material in the pedogenic dolomite palaeosols from the South Urals, ruling out this as a cause of the pedogenic dolomite. Pedogenic dolomite has also been identified in modern-day saline soils from Alberta where it is present as well-ordered crystals in the finest $<2 \mu \mathrm{m}$ fraction of the soil, which formed in isotopic equilibrium with the atmosphere (Kohut, Muehlenbacks \& Dudas, 1995). The isotopic composition of this dolomite has an average $\delta^{13} \mathrm{C}$ value of $-3.07 \%$ and average $\delta^{18} \mathrm{O}$ value of $-3.37 \%$ (Kohut, Muehlenbacks \& Dudas, 1995), which is similar to the isotopic values recorded in the Upper Permian dolomitic nodules in this study (Fig. 9).

The isotopic data from the Upper Permian and Lower Triassic palaeosol nodules analysed in this study show some overlap between the dolomite and calcite isotopic values (Fig. 9). Although one might expect more of a separation between these two fields, perhaps as much as $+2-4 \%$ in the $\delta^{18} \mathrm{O}$ values between the dolomite and calcite due to differences in isotopic fractionation (Goldstein pers. comm.), it is worth noting that the isotope values from unaltered, modern soils from Alberta also record some overlap between the dolomite and calcite fields (Fig. 9; Kohut, Muehlenbacks \& Dudas, 1995). In addition, Upper Permian-Lower Triassic palaeosols record dramatic fluctuations in both the $\delta^{18} \mathrm{O}$ and $\delta^{13} \mathrm{C}$ values of precipitated carbonate (MacLeod et al. 2000; Ward et al. 2005; Coney et al. 2007), reflecting isotopic changes in the atmosphere (Retallack et al. 2006). Given that the South Urals dataset comprises palaeosol nodules from 156 different stratigraphic horizons through the Permian-Triassic interval, the ranges of the calcite and dolomite fields would be expected to be far greater than in the modern and overlapping fields.

The presence of dolomite in the Alberta soils is thought to due to high carbonate ion concentration, elevated $\mathrm{Mg} / \mathrm{Ca}$ ratios, and low sulphur dioxide concentrations in the saline pore waters formed in evaporative environments (Kohut, Muehlenbacks \& Dudas, 1995). Earlier studies have also postulated that evaporation and $\mathrm{Mg} / \mathrm{Ca}$ ratios are important in dolomite precipitation. Watts (1980) suggested that, in times of increased evaporation, $\mathrm{Mg}$ will inhibit calcite nucleation and, if evaporation is greater than calcite nucleation, the $\mathrm{Mg} / \mathrm{Ca}$ ratio would remain constant but the salinity would increase. Dolomite is then precipitated by 'forced crystallization'. Thus it is likely that extreme evaporation, due to prevailing climatic changes, was one of the major controls on dolomite precipitation in the Upper Permian palaeosols.

Pedogenic dolomite is also more common in localities that are further away from the active channels, such as Tuyembetka. The presence of both dolomite and calcite within the same section, such as at Boyevaya Gora and Sambullak (Fig. 11), is possibly also related to temporal changes in the position of river channels and the proximity of individual palaeosols to the active palaeo-channel. Pedogenic nodules composed of calcite form closest to active channels, due to the raised water table producing damper soils (cf. William \& Krause, 1998).

Dolomite precipitation in the Upper Permian palaeosols from the South Urals may also have a biological control. Microbes have an important role in the formation of carbonate in modern soils and their presence leads to the development of characteristic clotted fabrics (e.g. Monger et al. 1991) Very similar clotted fabric textures are observed in the Upper Permian palaeosols in this study (Fig. 6b). Experiments using microbial cultures in both the field and laboratory have shown that the formation of dolomite through surface processes also requires the presence of certain bacteria (Roberts et al. 2004; Sánchez-Román et al. 2008) and this has also been observed in modern ephemeral lakes in South Australia (Wacey, Wright $\&$ Boyce, 2007). Therefore, it is plausible that the microbial communities living in the Upper Permian palaeosols of the South Urals may have played a central role in the formation of the dolomite recorded in the palaeosols in this study, although no evidence of such bacteria has been preserved in the palaeosols.

Finally, atmospheric conditions may also be crucial in the formation of primary dolomite. It has been suggested that elevated atmospheric $p \mathrm{CO}_{2}$ levels may cause the formation of dolomite rather than calcite in soils (Retallack pers. comm.). This is based on the observation that the carbonate precipitated in palaeosols during times of high atmospheric $p \mathrm{CO}_{2}$, such as during Precambrian time, is dolomitic rather than calcitic (Retallack \& Minsdzenty, 1994; Retallack, 2001). Possibly it is because elevated atmospheric $p \mathrm{CO}_{2}$ levels cause an increase in temperatures, and this increase in temperature may have made the precipitation of dolomite more kinetically likely (Arvidson \& Mackenzie, 1999). It is known that atmospheric $p \mathrm{CO}_{2}$ was much higher across the $\mathrm{P}-\mathrm{Tr}$ boundary than modern atmospheric levels (Retallack \& Jahren, 2008) and thus there was an increase in temperature.

If atmospheric or climatic conditions did control pedogenic dolomite formation, then the occurrence of primary, pedogenic dolomite in Upper Permian palaeosols should not be restricted to the South Urals Basin. Benito et al. (2005) and de la Horra et al. (2008) recorded dolomicrites in Upper Permian sections in the Iberian Ranges of Spain. While much of the dolomite observed in these Spanish sections has been attributed to a later diagenetic overprint (Gómez Gras \& AlonsoZarza, 2003; Benito et al. 2005) the observation of dolomicrites in some of the profiles has been used to suggest that they were originally developed as dolocretes in an arid to semi-arid climate (Benito et al. 2005; de la Horra et al. 2008). If this interpretation is correct then the presence of primary dolomicrite in both Spain and the South Urals, at the same time, would suggest that this phenomenon is not just related 


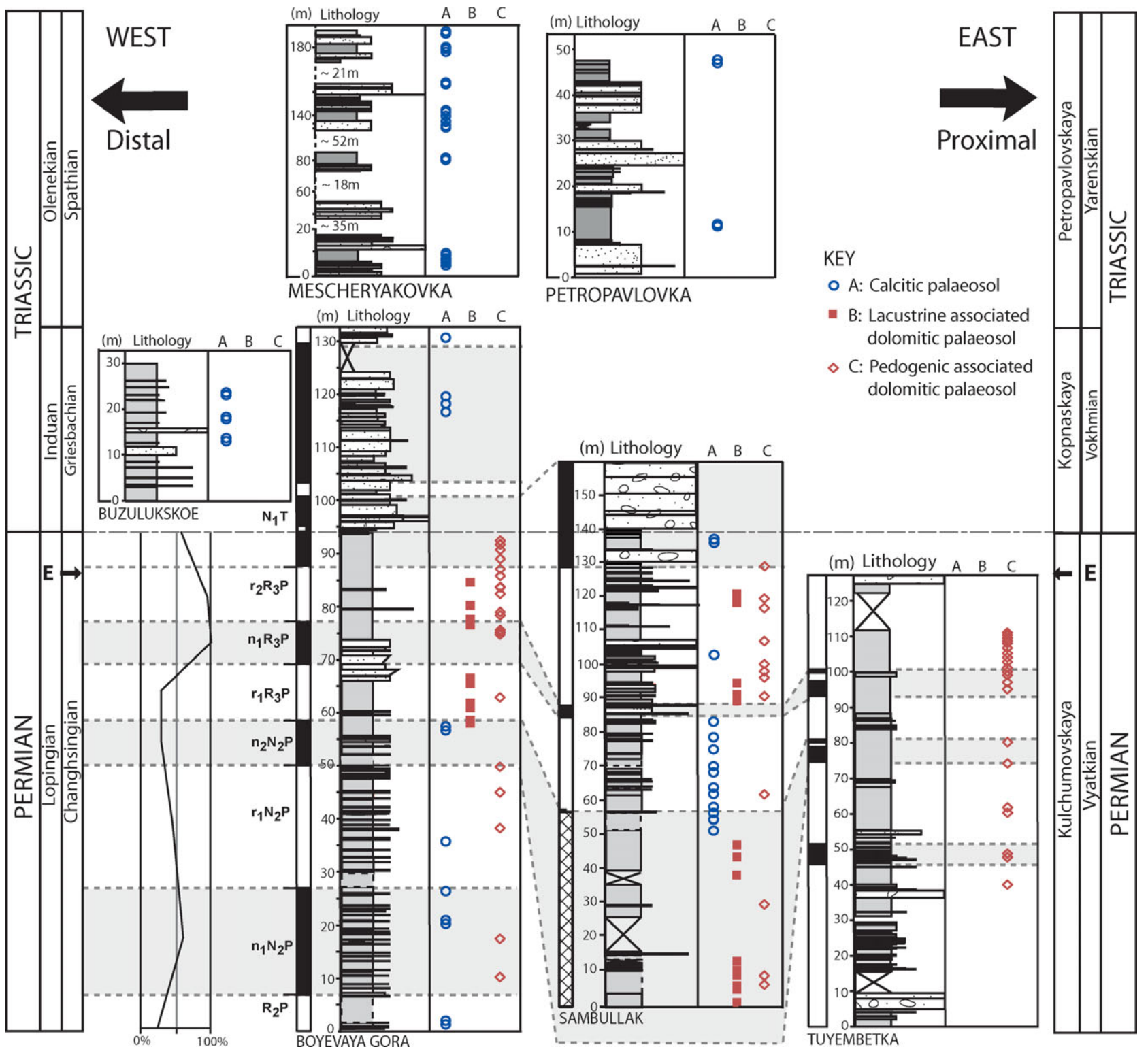

Figure 11. (Colour online) Stratigraphic distribution of calcite, lacustrine dolomite and pedogenic dolomite in palaeosols from Boyevaya Gora, Tuyembetka, Sambullak Buzulukskoe, Petropavlovka and Mescheryakovka. Palaeomagnetic data from Taylor et al. (1999). The line graph on the far left shows percentage of the pedogenic dolomitic palaeosols across the basin for the specific chron. Arrowed $\mathrm{E}$ indicates position of mass extinction horizon, from the global composite magnetostratigraphic correlation of Hounslow et al. (2008).

to local basin conditions, but may relate to larger-scale climatic trends.

\section{5.d. Stratigraphic distribution of dolomite}

Pedogenic dolomite and calcite are not evenly distributed through the sections. There is an increase in the frequency of pedogenic dolomite, with respect to calcite, up-section, and dolomitic palaeosols are most prevalent in the uppermost Changhsingian just beneath the $\mathrm{P}-\mathrm{Tr}$ boundary (Fig. 11). Palaeosols above the $\mathrm{P}-\mathrm{Tr}$ boundary contain no dolomite (Fig. 11).

The stratigraphic distribution of dolomite provides further evidence for a primary pedogenic origin for the dolomite (Fig. 11). If all the palaeosols had originally been calcitic and later replaced by dolomite, the dolomite should be present in both the Permian and Triassic palaeosols. There is no significant time gap between the Permian and Triassic strata of the study area (Taylor et al. 2009), and therefore the Permian and Triassic strata cannot have experienced different burial histories. Equally there is no evidence of such features as isopachous rims of dolomitic angular phreatic cements in the Permian dolomitic nodules that may suggest different diagenetic histories. The presence or absence of dolomite is therefore related to the primary properties of the palaeosols and their environment.

The occurrence of possible pedogenic dolomite in the Upper Permian of Spain has also been used as evidence for an arid to semi-arid climate with marked seasonality (Benito et al. 2005). In Spain, however, 
the dolomite disappears by the Changhsingian and it is thought that conditions became more humid towards the P-Tr boundary (de la Horra et al. 2008). In the South Urals the pedogenic dolomite does not disappear until after the $\mathrm{P}-\mathrm{Tr}$ boundary (Fig. 11), suggesting a later onset of more humid conditions in the South Urals. Although more studies are needed, these regional differences may indicate northward shift of climatic belts through the Changhsingian interval.

The complete absence of Lower Triassic dolocretes may indicate that evaporation rates and seasonality were reduced in the study area in earliest Triassic time, compared to the situation in latest Permian time. The change from meandering rivers to braided river systems observed in the South Urals across the P-Tr boundary meant that there would have been an increase in the rate of surface runoff, greater flood peaks (Newell, Tverdokhlebov \& Benton, 1999) and potentially wetter soils during Early Triassic time as rivers were no longer constrained in meandering river channels. This interpretation is supported by the occurrence of gleyed soils in the Triassic (Palaeosols Type E and F, Table 1), suggesting higher water tables and the presence of anoxic standing water. This increased soil moisture would have likely resulted in the precipitation of calcite rather than dolomite. An alternative hypothesis is that pedogenic dolomite formation is not primarily controlled by extreme evaporation, and that soil conditions changed dramatically across the $\mathrm{P}-\mathrm{Tr}$ boundary as a result of the mass extinction.

\section{Summary}

A combination of analyses has demonstrated the unequivocal presence of primary dolomite in unaltered pedogenic nodules from the Upper Permian (Changhsingian Stage) of the South Urals, Russia. Dolomite is also associated with lacustrine deposits formed during evaporation of ephemeral lakes or ponds in a semi-arid setting. The presence and distribution of pedogenic dolomite indicate that immediately prior to the $\mathrm{P}-\mathrm{Tr}$ boundary in this region there was an increase in seasonality and extreme evaporation. A change to purely calcitic palaeosols in earliest Triassic time may reflect (a) hydrological changes possibly related to the dramatic change in river morphology observed in the South Urals by Newell, Tverdokhlebov \& Benton (1999), (b) reduction in evaporation rates and seasonality in the study area, and/or (c) disappearance of the soil microbes that are necessary for dolomite formation.

Acknowledgements. TK was funded through a University of Plymouth, Faculty of Science Ph.D. Studentship, which also funded all laboratory analyses. TK thanks S. T. Grimes, G. D. Price, P. A. Sutton and R. M. Moate for discussion and assistance in the laboratory. Samples were collected during fieldtrips funded by National Geographic (7469-03) (2004) and NERC (NE/C518973/1) (2006). Thanks to G. K. Taylor for discussion of the palaeomagnetic data. M. J. Benton, M. Surkov and V. Tverdokhlebov are thanked for assistance in the field and logistic support. We would like to thank Prof. G. J. Retallack and Prof. G. S. Soreghan for critical comments on an earlier draft of the manuscript. We thank two anonymous reviewers for their reviews of this paper.

\section{References}

Allman, M. \& LAWRENCE, D. F. 1972. Geological Laboratory Techniques. London: Blandford Press, $335 \mathrm{pp}$.

Alonso-ZARZA, A. M. 2003. Palaeoenvironmental significance of palustrine carbonates and calcretes in the geological record. Earth Science Reviews 60, 261-98.

Arche, A. \& LÓPEZ-GómEZ, J. 2005. Sudden changes in fluvial style across the Permian-Triassic boundary in the eastern Iberian Ranges, Spain: analysis of possible causes. Palaeogeography, Palaeoclimatology, Palaeoecology 229, 104-26.

ARVidson, R. S. \& MACKEnZIE, F. T. 1999. The dolomite problem: control of precipitation kinetics by temperature and saturation state. American Journal of Science 299, 257-88.

Benton, M. J., TVerdokhlebov, V. P. \& Surkov, M. V. 2004. Ecosystem remodelling among vertebrates at the Permian-Triassic boundary in Russia. Nature 432, 97 100.

Benito, M. I., de la Horra, R., Barrenechea, J. F., LÓPEZ-GÓMEZ, J., RodAs, M., AlONSO-AZCÁRATE, J., ARCHE, A. \& LUQUE, J. 2005. Late Permian continental sediments in the SE Iberian Ranges, eastern Spain: petrological and mineralogical characteristics and palaeoenvironmental significance. Palaeogeography, Palaeoclimatology, Palaeoecology 229, 24-39.

Bestland, E. A. \& KRULL, E. S. 1999. Palaeoenvironments of Early Miocene Kisingiri volcano Proconsul sites: evidence from carbon isotopes, palaeosols and hydromagmatic deposits. Journal of the Geological Society, London 156, 965-76.

Bui, E. N., Loeppert, R. H. \& Wilding, L. P. 1990. Carbonate phases in calcareous soils of the Western United States. Soil Science Society of America 54, 39 45.

Bustillo, M. A. \& Alonso-ZarzA, A. M. 2007. Overlapping of pedogenesis and meteoric diagenesis in distal alluvial and shallow lacustrine deposits in the Madrid Miocene Basin, Spain. Sedimentary Geology 196, 25571.

Calvo, J. P., Jones, B. F., Bustillo, M. A., Fort, R., Alonso-Zarza, A. M. \& Kendall, C. 1995. Sedimentology and geochemistry of carbonates from lacustrine sequences in the Madrid Basin, Central Spain. Chemical Geology 123, 173-91.

CAPO, R. C., WHIPKEY, C. E., BLACHÈRE, J. R. \& CHADWICK, O. A. 2000. Pedogenic origin of dolomite in a basaltic weathering profile, Kohala peninsula, Hawaii. Geology 28, 271-4.

COLSON, J. \& COJAN, I. 1996. Groundwater dolocretes in a lake-marginal environment: an alternative model for dolocrete formation in continental settings (Danian of the Provence Basin, France). Sedimentology 43, 17588.

Coney, L., Reimold, W. U., Hancox, P. J., Mader, D., KoEberl, C., MCDONALD, I., StruCK, U., VAJdA, V. \& KAMO, S. L. 2007. Geochemical and mineralogical investigation of the Permian-Triassic boundary in the continental realm of the southern Karoo Basin, South Africa. Palaeoworld 16, 67-107.

Del Cura, M. A. G., Calvo, J. P., OrdóÑez, S., Jones, B. F. \& CAÑAVERAS, J. C. 2001. Petrographic and 
geochemical evidence for the formation of primary bacterially induced lacustrine dolomite; La Roda 'white earth' (Pliocene, central Spain). Sedimentology 48, 897915.

DE LA Horra, R., Benito, M. I., LÓPEZ-GÓMEZ, J., ArChe, A., Barrenechea, J. F. \& LuQue, J. 2008. Palaeoenvironmental significance of Late Permian palaeosols in the South-Eastern Iberian Ranges, Spain. Sedimentology 55, 1849-73.

DiCKSON, J. A. D. 1966. Carbonate identification and genesis as revealed by staining. Journal of Sedimentary Petrology 36, 491-505.

ERwIN, D. H. 2006. Extinction: How life on earth nearly ended 250 million years ago. Princeton: Princeton University Press, 296 pp.

GASTALDO, R. A. \& Rolerson, M. W. 2008. Katbergia gen. nov., a new trace fossil from Upper Permian and Lower Triassic rocks of the Karoo Basin: implications for palaeoenvironmental conditions at the $\mathrm{P} / \mathrm{Tr}$ extinction event. Palaeontology 51, 215-29.

GHosh, P., GHosh, P. \& BHATTACHARYA, S. K. 2001. $\mathrm{CO}_{2}$ levels in the Late Palaeozoic and Mesozoic atmosphere from soil carbonate and organic matter, Satpura basin, Central India. Palaeogeography, Palaeoclimatology, Palaeoecology 170, 219-36.

GÓMEZ-GRAS, D. \& ALONSO-ZARZA, A. M. 2003. Reworked calcretes: their significance in the reconstruction of alluvial sequences (Permian and Triassic, Minorca, Balearic Islands, Spain). Sedimentary Geology 158, 299-319.

Hounslow, M. W., Peters, C., Mørk, A., Weitschat, W. \& OS VIGRAN, J. 2008. Biomagnetostratigraphy of the Vikinghøgda Formation, Svalbard (Arctic Norway), and the geomagnetic polarity timescale for the Lower Triassic. Geological Society of America Bulletin 120, 1305-25.

JoInt COMmitTeE ON POWDER Diffraction STANDARDS. 1971. Inorganic Index to the Powder Diffraction File Pennsylvania. Joint Committee on Powder Diffraction Standards, $1322 \mathrm{pp}$.

Kearsey, T., Twitchett, R. J., Price, G. D. \& Grimes, S. T. 2009. Isotope excursions and palaeotemperature estimates from the Permian/Triassic boundary in the Southern Alps (Italy). Palaeogeography, Palaeoclimatology, Palaeoecology 279, 29-40.

Kessler, J. L. P., Soreghan, G. S. \& Wacker, H. J. 2001. Equatorial aridity in western Pangea: Lower Permian loessite and dolomitic paleosols in northeastern New Mexico, USA. Journal of Sedimentary Research 71, 817-32.

KHADKIKAR, A. S., CHAMYAL, L. S. \& RAMESH, R. 2000. The character and genesis of calcrete in Late Quaternary alluvial deposits, Gujartat, western India, and its bearing on the interpretation of ancient climates. Palaeogeography, Palaeoclimatology, Palaeoecology 162, 239-61.

KIDDER, D. L. \& Worsley, T. R. 2004. Causes and consequences of extreme Permo-Triassic warming to globally equable climate and relation to the PermoTriassic extinction and recovery. Palaeogeography, Palaeoclimatology, Palaeoecology 203, 207-37.

KohUt, K., MuehlenbaCKs, K. \& DudAS, M. J. 1995. Authigenic dolomite in a saline soil in Alberta, Canada. Soil Science Society of America Journal 59, 1499504.

KRULL, E. S. \& RetallacK, G. J. 2000. 813 C depth profiles from paleosols across the Permian-Triassic boundary: Evidence for methane release. Geological Society of America Bulletin 112, 1459-72.
LEEDER, M. 1999. Sedimentology and Sedimentary Basins: From Turbulence to Tectonic. Oxford: Blackwells Science Ltd, $592 \mathrm{pp}$.

Mack, G. H., James, W. C. \& Monger, H. C. 1993. Classification of paleosols. Geological Society of America Bulletin 105, 129-36.

MACHETTE, M. N. 1985. Calcic soils of southwestern United States. In Soil and Quaternary Geology of the Southwestern United States (ed. D. L. Weide), pp. 1-21. Geological Society of America Special Paper 203.

MACLEOD, K. G., SMITH, R. M. H., Koch, P. L. \& WARD, P. D. 2000. Timing of mammal-like reptile extinctions across the Permian-Triassic boundary in South Africa. Geology 28, 227-30.

MiLleR, J. 1988. Microscopical techniques I. Slices, slides, stains and peels. In Techniques in Sedimentology (ed. M. E. Tucker), pp. 86-107. Oxford: Blackwell Science.

Monger, H. C., LeRoy, A. D., LindemanN, W. C. \& LidDELL, C. M. 1991. Microbial precipitation of pedogenic calcite. Geology 19, 997-1000.

Newell, A. J., TVERDOKHLEBOV, V. P. \& BENTON, M. J. 1999. Interplay of tectonics and climate on a transverse fluvial system, Upper Permian, Southern Uralian Foreland Basin, Russia. Sedimentary Geology 127, 11-29.

Pace, D. W., Gastaldo, R. A. \& Neveling, J. 2009. Early Triassic aggradation and degradation landscapes of the Karoo Basin and evidence for climate oscillations following the $\mathrm{P}-\mathrm{Tr}$ event. Journal of Sedimentary Research 79, 316-31.

QuAst, A., HoEfS, J. \& PAUL, J. 2006. Pedogenic carbonates as a proxy for palaeo- $\mathrm{CO}_{2}$ in the Palaeozoic atmosphere. Palaeogeography, Palaeoclimatology, Palaeoecology 242, 110-25.

RETALLACK, G. J. 1993. Classification of paleosols: discussion. Geological Society of America Bulletin 105, 383400.

Retallack, G. J. 2001. Soils of the Past - An Introduction to Paleopedology. Oxford: Blackwell Science, $404 \mathrm{pp}$.

Retallack, G. J. \& JAHREN, A. H. 2008. Methane release from igneous intrusion of coal during Late Permian extinction events. Journal of Geology 116, 1-20.

Retallack, G. J. \& KrULl, E. S. 1999. Landscape ecological shift at the Permian-Triassic boundary in Antarctica. Australian Journal of Earth Sciences 46, 785-812.

Retallack, G. J., MetzGer, C. A., Greaver, T., Jahren, A. H., SMith, R. M. H. \& SHELDON, N. D. 2006. MiddleLate Permian mass extinction on land. Geological Society of America Bulletin 118, 1398-411.

RETALLACK, G. J. \& MinDSZENTY, A. 1994. Well preserved Late Precambrian paleosols from northwest Scotland. Journal of Sedimentary Research A64, 264-81.

Retallack, G. J., SMith, R. M. H. \& WARD, P. D. 2003. Vertebrate extinction across Permian-Triassic boundary in Karoo Basin, South Africa. Geological Society of America Bulletin 115, 1133-52.

Roberts, J. A., Bennett, P. C., Gonzalez, L. A., MACPHERSON, G. L. \& MiLliKen, K. L. 2004. Microbial precipitation of dolomite in methanogenic groundwater. Geology 32, 277-80.

SÁnchez-Román, M., VASCONCElos, C., Schmid, T., DitTrich, M., McKenzie, J. A., ZenobI, R. \& RIVADENEYRA, M. A. 2008. Aerobic microbial dolomite at the nanometer scale: Implications for the geologic record. Geology 36, 879-82.

Sheldon, N. D. \& Retallack, G. J. 2002. Low oxygen levels in earliest Triassic soils. Geology 30, 919-22. 
SHELdON, N. D. \& TABOR, N. J. 2009. Quantitative paleoenvironmental and paleoclimatic reconstruction using paleosols. Earth Science Reviews 95, 1-52.

SHERMAN, L. A. \& BARAK, P. 2000. Solubility and dissolution kinetics of dolomite in $\mathrm{Ca}-\mathrm{Mg}-\mathrm{HCO}_{3} / \mathrm{CO}_{3}$ solutions at 25 degrees $\mathrm{C}$ and $0.1 \mathrm{MPa}$ carbon dioxide. Soil Science Society of America Journal 64, 1959-68.

Soil Survey Staff. 1999. Soil Taxonomy: A Basic System of Soil Classification for Making and Interpreting Soil Surveys, Agriculture Handbook Number 436. United States Department of Agriculture Natural Resources Conservation Service, $871 \mathrm{pp}$.

SPÖTL, C. \& Wright, V. P. 1992. Groundwater dolocretes from the Upper Triassic of the Paris Basin, France a case-study of an arid, continental diagenetic facies. Sedimentary Geology 39, 1119-36.

STEINER, M. B. 2006. The magnetic polarity time scale across the Permian-Triassic boundary. In Non-Marine Permian Biostratigraphy and Biochronology (eds S. G. Lucas, G. Cassinis \& J. W. Schneider), pp. 15-38. Geological Society of London, Special Publication no 265.

Surkov, M. V., BENTON, M. J., TwitcheTt, R. J., TVerdokhlebov, V. P. \& Newell, A. J. 2007. First occurrence of footprints of large therapsids from the Upper Permian of European Russia. Palaeontology 59, 641-52.

TABOR, N. J., MontAnez, I. P., STEINER, M. B. \& SCHWIndT, D. 2007. Delta C-13 values of carbonate nodules across the Permian-Triassic boundary in the Karoo Supergroup (South Africa) reflect a stinking sulfurous swamp, not atmospheric $\mathrm{CO}_{2}$. Palaeogeography, Palaeoclimatology, Palaeoecology 252, 370-81.

TAylor, G. K., TUCKer, C., Twitchett, R. J., KeArsey, T., Benton, M. J., Newell, A. J., Surkov, M. V. \& TVERDOKHLEBOV, V. P. 2009. Magnetostratigraphy of Permian/Triassic boundary sequences in the Cis-Urals, Russia: No evidence for a major temporal hiatus. Earth and Planetary Science Letters 281, 36-47.

TVERdOKhleBOV, V. P., TVERDOKHLEBOVA, G. I., MiniKh, A. V., Surkov, M. V. \& Benton, M. J. 2005. Upper Permian vertebrates and their sedimentological context in the Southern Urals, Russia. Earth Science Reviews 69, 27-77.

TVERDOKHLEBOV, V. P., TVERdOKHLEBOVA, G. I., SuRKov, M. V. \& BENTON, M. J. 2002. Tetrapod localities from the Triassic of the SE of European Russia. Earth Science Reviews 60, 1-66.
Ufnar, D. F., Gröcke, D. R. \& Beddows, P. A. 2008. Assessing pedogenic calcite stable-isotope values: can positive linear covariant trends be used to quantify palaeo-evaporate rates? Chemical Geology 256, $46-51$.

VAhrenKamp, V. C. \& SwarT, P. K. 1994. Late Cenozoic dolomites of the Bahamas: metastable analogues for the genesis of ancient platform dolomites. Special Publications of the Institute of Associated Sedimentology 21, 133-53.

VAN DER VOO, R. \& TORSVIK, T. H. 2004. The quality of the European Permo-Triassic paleopoles and its impact on Pangea reconstructions. In Timescales of the Paleomagnetic Field (eds J. E. T. Channel, D. V. Kent, W. Lowrie \& J. G. Meert), pp. 29-42. American Geophysical Union, Geophysical Monograph vol. 145. Washington DC, USA.

WACEY, D., Wright, D. T. \& Boyce, A. J. 2007. A stable isotope study of microbial dolomite formation in the Coorong Region, South Australia. Chemical Geology 244, 155-74.

WARD, P. D., BOTHA, J., BUICK, R., DE Kock, M. O., ERWIN, D. H., Garrison, G. H., KirschVinK, J. L. \& SMith, R. 2005. Abrupt and gradual extinction among Late Permian land vertebrates in the Karoo Basin, South Africa. Science 307, 709-14.

WATTS, N. L. 1980. Quaternary pedogenic calcretes from the Kalahari (southern Africa): mineralogy, genesis and diagenesis. Sedimentology 27, 661-86.

Williams, C. A. \& KRAUSE, F. F. 1998. Pedogenic-phreatic carbonates on a Middle Devonian (Givetian) terrigenous alluvial-deltaic plain, Gillwood member (Watt Mountain formation), northcentral Alberta, Canada. Sedimento$\log y \mathbf{4 5}, 1105-24$.

Wright, V. P. \& TuCKer, M. E. 1991. Calcretes - an introduction. In Calcretes (eds V. P. Wright \& M. E. Tucker) pp. 1-22. Oxford: Blackwell Scientific Publications.

Wright, D. T. \& WACEY, D. 2005. Precipitation of dolomite using sulphate-reducing bacteria from Coorong Region, South Australia: significance and implications. Sedimentology 52, 987-1008.

WyNN, J. G. 2007. Carbon isotope fractionation during decomposition of organic matter in soils and paleosols: implications for paleoecological interpretations of paleosols, Palaeogeography, Palaeoclimatology, Palaeoecology 251, 437-48. 